\title{
Spatial distribution, territoriality and sound production by tropical cryptic butterflies (Hamadryas, Lepidoptera: Nymphalidae): implications for the "industrial melanism" debate
}

\author{
Julián Monge-Nájera 1, Francisco Hernández 2, María Isabel González ${ }^{3}$, Javier Soley ${ }^{4}$, José \\ Araya ${ }^{4}$ and Stefano Zolla 5
}

1 Centro de Investigación Académica, UNED, Costa Rica. Mailing address: Biología Tropical, Universidad de Costa Rica, 2060 Costa Rica; fax (506)2075550; julianm@ @ariari.ucr.ac.cr.

2 Unidad de Microscopia Electrónica, ${ }^{3}$ Escuela de Estadística, 4 Escuela de Física, Universidad de Costa Rica, 2060 Costa Rica

5 Centro Intemazionale Crocevia, Via Ferraironi 88G, 00172, Roma, Italy.

Received 23-V-1997. Corrected 19-II-1998. Accepted 13-III-1998.

\begin{abstract}
Neotropical butterflies of the genus Hamadryas, noted by the emission of sound, spend much time perching on trees and are believed to be cryptically pattemed and colored with respect to tree trunks and branches they use as perching sites, but the subject had not been studied previously. This paper describes spatial distribution, territoriality and sound production in five species, under natural conditions: Hamadryas amphinome (Lucas, 1853), H. februa (Godart, 1824), H. feronia (Fruhstorfer, 1916), H. glauconome (Bates, 1864) and $H$. guatemalena (Bates, 1864). Tree characteristics and use by butterflies were recorded under natural conditions in open habitats (grassland thinly covered with trees) in Costa Rica and Panama, avoiding the problems that affected previous natural selection studies in Biston betularia (the "industrial melanism" moth). Males perched on the trees and used them as courting territories. The butterflies perched more often on some individual trees, and did not use others. The general tree bark ("background") color tended to match wing coloration, while presence of food, position of trees along flight routes, tree size, bark texture, and lichen cover were not associated with the frequency of perching on the trees. Most individuals that perched in the study sites were males. Species differed in perching height and populations of $H$. februa perched at the same heights in both countries; $H$. feronia moves to higher perches near day's end. The relative use of branches and trunks is not related to the time of day but reflects the typical perching height of each species. The northem side of trees is less used and cardinal side distribution is independent of time of day. Perches exposed to direct sunlight are less used in hot days. All species perch with the head downwards. Perching males frequently fly towards other Hamadryas as well as towards tethered cardboard models. Trees with experimentally removed males were taken by newcomers 32 times more often than trees with resident males. Each marked $H$. feronia male was seen perching on 1-4 trees daily, without difference between seasons, and each tree used had a minimum daily mean of 1.5 perching butterflies. Most $H$. feronia interactions occur from 13:00 through 15:00 hours and are more frequent in the rainy season. At night males share perches. Sound emission was studied by using non-destructive experimental methods $(\mathrm{N}=858)$ and with a scanning electron microscope. Both sexes emit sound and the sound apparatus, located in the forewing, is percussive, not stridulatory. At the end of the upward wingstroke, the wings are clapped and modified $\mathrm{r}-\mathrm{m}_{1-2}$ veins meet at a speed of approximately $1420 \mathrm{~mm} / \mathrm{s}$, producing the characteristic clicks. Wingbeat frequency of free-flying individuals is $20-29 \mathrm{~Hz}$. There is some wing deformation during movement. Clicks last a mean of $1.38 \mathrm{~ms}$ with mean intervals of $43.74 \mathrm{~ms}$ and the component frequencies concentrate around $2.4 \mathrm{kHz}$, matching Hamadryas hearing capacity and being appropriate for the acoustic conditions of habitat. The swollen Sc vein is present exclusively in Hamadryas; has a serpentine structure inside
\end{abstract}


and probably acts as resonance box. Growth of the sound apparatus may be checked by its effect on flight capacity, physiological costs and ecological reasons. All Hamadryas have a membrane, shaped as an elongated cupola, in the costal cell, that acts as ear. A second and smaller ear has four chambers and may detect predatory bats when the insects are perching at night. Field observations showed that Hamadryas spp. emit audible clicks when approached by potential predators, to defend territories from other Hamadryas and in at least one species also during courtship. Severe wing damage, common in wild Hamadryas, almost never affects the section with the sound mechanism. A review of the literature shows that more than 50 species of lepidopterans ( 11 families) emit sound audible to humans and suggests that sound mechanisms evolved several times. In general, lepidopteran sound is used basically as a warning to predators and for intraspecific communication.

Key words: Behavior, protective coloration, crypsis, industrial melanism, territoriality, spatial distribution, sound, stridulation, mechanism, wing structure, defense, mating, courtship, communication.

Crypsis, a phenomenon in which organisms receive some protection from predators and other enemies because they are difficult to distinguish from their background, is important in evolutionary theory (Cott 1946, Pasteur 1972, Steward 1977 b). Butterflies of the genus Hamadryas spend much time perching on tree trunks on which they are believed to be cryptic, but the consequences of this behavior have not been studied (Young 1974, Jenkins 1983). Despite the fact that the genus has been known for two centuries, there are no studies of tree use; information is mostly limited to taxonomy and life cycles (reviews in Jenkins 1983 and Monge-Nájera 1992).

Spatial distribution and particularly vertical stratification has seldom been studied in butterflies (De Vries 1988, Daily et al. 1991). De Vries (1988) lamented the lack of detailed studies comparing species that are phylogenetically close. The relationship of spatial distribution with interactions that appear to be territorial is also very poorly known (Monge-Nájera 1992).

Territoriality is one of the most debated topics in lepidopteran ethology. Darwin (1871) proposed that the joint "spiral" flights of butterflies were part of courtship, and Joy (1902) associated these flights with reproductive territoriality.

Contemporarily, authors such as Scott (1974) have rejected the territorial interpretation and suggested that joint flights simply are identification attempts by the pursuing male. Basically, territoriality has been denied on two grounds: (a) alleged owners do not always return to the territory after aerial interactions and (b) lepidopterans in general lack harmful fighting structures (Baker 1972). However, it is now known that there are several perches in a territory (Bitzer \& Shaw 1979, 1983); this can explain why some authors believed that males did not always return to the same "territory" (perch, actually).

Territoriality models which do not require physical aggression are now available (review in Thornhill and Alcock 1983) and Davies (1978) found evidence that such is the case in the butterfly Pararge aegeria. Nevertheless, Wickman (1983) proved with film analysis that physical aggression occurs in the species. Aggression and wing damage during spiral flights is also known to exist in tropical butterflies (Pinheiro 1990).

Neotropical butterflies of the genus Hamadryas are good subjects for territoriality study because of their large size and the peculiarity of emitting audible sound (MongeNájera 1988, 1992, Monge-Nájera and Hernández 1993). They align on trees and the species studied here have a wing calico pattern that is cryptic on bark (Jenkins 1983). Adults feed on fermented liquids and usually emit the sounds when two or more fly in circles ("spiral flights"), a behavior that has been variously 
interpreted as - defense, territoriality or courtship (Swinton 1877, Hampson 1892, Darwin 1839, 1871, Swihart 1967, MongeNájera 1992).

Production of sounds audible to humans has been reported for more than 56 species of lepidopterans covering the families Agaristidae (Laithwaite et al. 1974); Arctiidae (Haskell 1961, Rothschild \& Haskell 1966, Lloyd 1974); Lymantriidae (Haskell 1961); Nymphalidae (Hampson 1892, Busnell 1963, Dumortier 1963, Scott 1968); Noctuidae (Darwin 1871, Hampson 1892, Hebard 1922, Hannemann 1956, Haskell 1961, Dumortier 1963, McCrae 1975, Wakamura 1977, Bailey 1978, Alcock 1989); Papilionidae (Haskell 1961, Busnell 1963); Pericopidae (Rothschild and Haskell 1966); Satyridae (Kane 1982); Sphingidae (Haskell 1961, Rothschild and Haskell 1966) and Zygaenidae (Rothschild \& Haskell 1966).

In the XIX century, two hypothetical mechanisms were proposed to explain the evolution of sound in adult lepidopterans: sexual selection and natural selection. In sexual selection (Darwin 1871, Hampson 1892) sound may often be a male characteristic (Rothschild and Haskell 1966). In contrast, White (1877) suggested natural selection arguing that if sound is defensive it would be more developed in the females because they are more closely associated with the offspring.

For the genus Hamadryas, the oldest report of sound may be that of Langsddorf (1805, cited by Darwin 1839), for Hamadryas februa in Brazil. Early authors mentioned several structures that they thought related to sound emission, but published no detailed descriptions or illustrations (e.g. Swinton 1877, Hampson 1892), with the exception of Hampson (1892) who illustrated "hooks and vesicles" whose existence was not supported by later observations (Calvert and Calvert
1917, Monge-Nájera 1992, Monge-Nájera and Hernández 1993). Photographs of organs proposed as the origin of sound show in fact rami, structures associated with copulation (Jenkins 1983, Monge-Nájera 1992).

In total, seven competing hypotheses have tried to explain how the sound is produced in Hamadryas, but they were not subjected to experimental tests (Otero 1990, Monge-Nájera 1992). Morphological observations which compared "mute" and sound emitting species of several genera suggested that modified forewing veins allowed clicking by percussion in Hamadryas (Monge-Nájera 1988, MongeNájera \& Hernández 1993).

Otero (1990) described a procedure to elicit sound production in tethered individuals (an unclear remark in Seitz 1914 could be interpreted to refer to the same procedure) and reported that sound was not produced after removal of the $r-m_{1-2}$ veins, concluding that the strike of both wings at the end of the upstroke was the probable cause of sound as originally hypothesized by Seitz (1914).

However, the test (Otero 1990) did not include surgical controls, and the butterflies may have ceased sound production because of the surgical shock even if the sound apparatus was located somewhere else. To avoid this problem, there was need for a non-destructive procedure that could inactivate any hypothetical sound structures intermittently.

This paper describes Hamadryas spp. spatial distribution and its relation to wing coloration under natural conditions, analyses the territorial interpretation of aerial interactions and presents field observations about sound, a solution to the experimental problem of ablation, a computer analysis of sonic emissions and an ultrastructural description of sound-associated structures in Hamadryas spp. 


\section{MATERIALS AND METHODS}

Study sites: Tree use was studied in open areas (grassland with some trees) that previously had been moist "forest" in Panama and Costa Rica (Figs. 1-3). This habitat was selected because several Hamadryas species are associated with forest clearings, and with increasing deforestation they have become established in open areas such as cattle pasture, where they fly along belts of riparian vegetation and vegetated fence lines (Young 1974, Jenkins 1983).

Sites 1 and 2 were located less than $100 \mathrm{~m}$ from the Panama Canal, in the Soberanía National Park, about $2 \mathrm{~km}$ NE of the town of Gamboa, Panama. Site 3 was located at mid way between the towns of Turrúcares and Cebadilla, Alajuela Province, Costa Rica. Tree species appear in Tables 1 and 2, and spatial arrangements in Figs. 1-3.
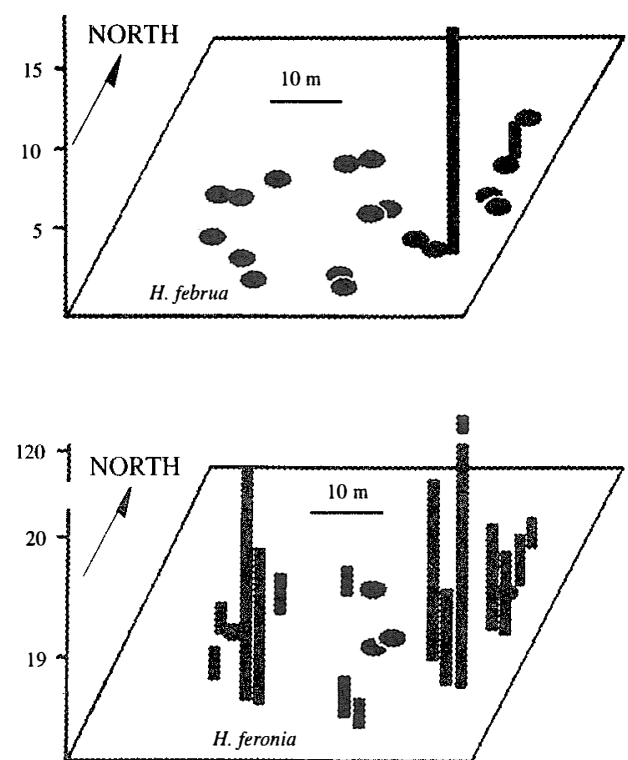

Fig. 1. Use of trees by perching Hamadryas butterflies at Site 1 (Panama). The map is to scale; the ovals represent trees with no use records; and the bar height (scale at left) indicates the total count of butterflies perching on each tree during the observation period.
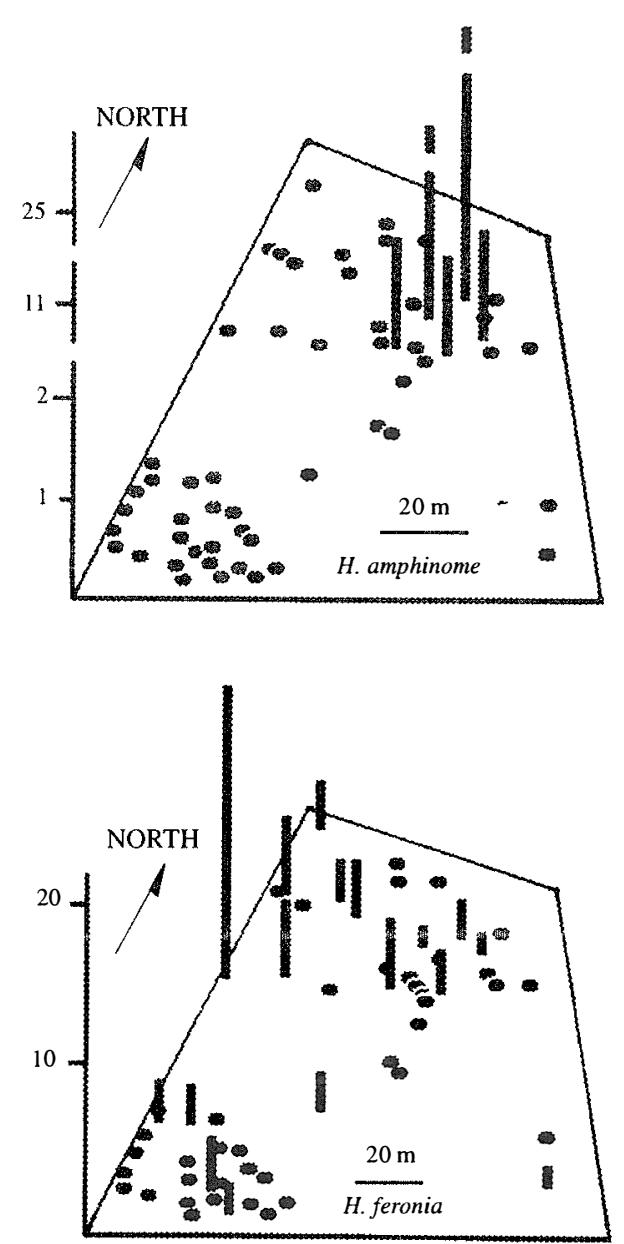

Fig. 2. Use of trees by perching Hamadryas butterflies at Site 2 (Panama). Explanation in Fig. 1

At Site 1 the ground was flat and covered by leaf litter and some grass. Tree trunks were mainly mottled gray, and were straight and mostly branched $3 \mathrm{~m}$ or more above the ground. Most branches were long and grew upwards forming oval canopies. Some trees produced fruit during the study period. The ground in Site 2 also was flat and horizontal, but it was covered mainly by grass. Tree trunks were mottled gray or brownish, and were short and not straight, often branching at less than 1 $\mathrm{m}$ from the ground. Canopies often had the shape of inverted triangles because branches grew at angles of nearly 45 degrees. There were almost no fruits during the study period. Site 3 was on the side of a hill (about 20 

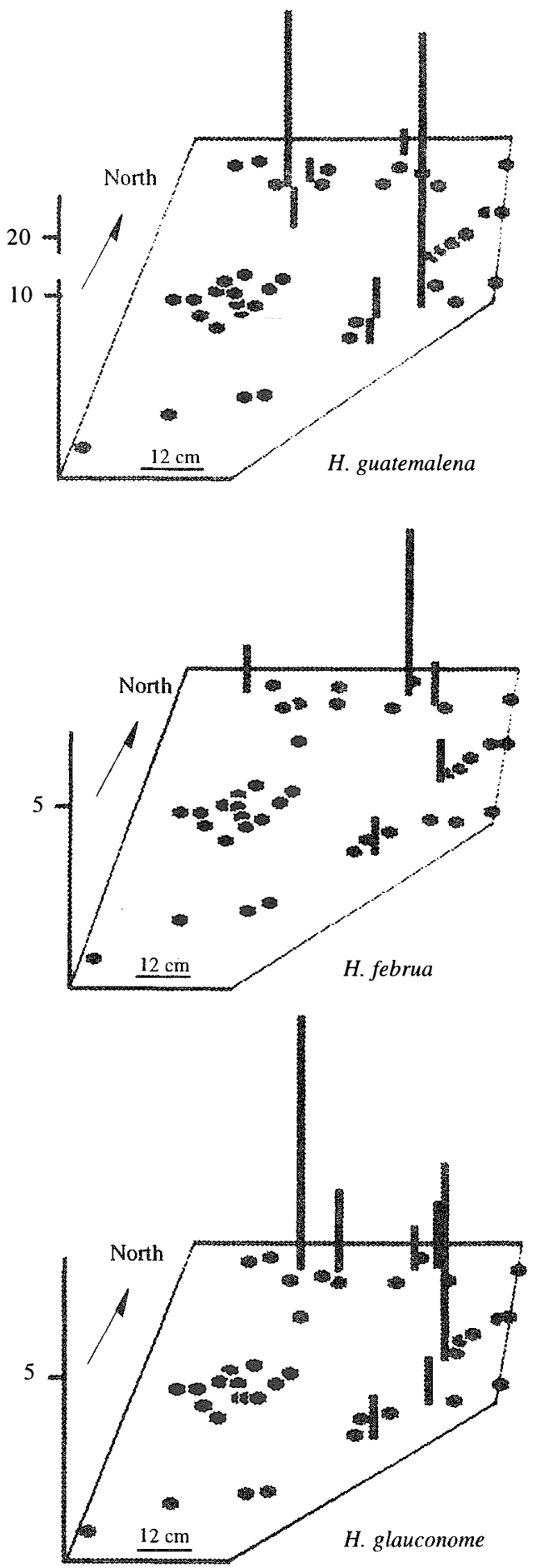

Fig. 3. Use of trees by perching Hamadryas butterflies at Site 3 (Costa Rica). Explanation in Fig. 1. degrees inclination) covered by grass and weeds. Tree trunks were mainly brownish or mottled gray and contorted, often branching about $1 \mathrm{~m}$ above the ground. Many branches were long, and canopy shape was similar to that of Site 2. The site included a small pond, muddy areas, and abundant fallen fruit that was consumed both by the butterflies and the cattle that moved through the area almost daily.

Site 1 had the tallest trees, and Site 3 the shortest; trunks were thicker in Site 3, and thinner in Site 2. Only in Site 3 did some of the trees lose foliage during the dry period. Site 2 differed from the others in having two patches in which the canopy was thick enough to produce areas of low light on trunks and the ground. Detailed study of some tree characteristics was done only in Site 3.

Data collection: Field data were taken during the early years of a study that began in 1983. The Panamanian sites were studied intensively (37 days within a 1.4 month period), and the Costa Rican site over a longer period (30 visits distributed at convenience during a five year period). At each visit, all trees were checked with binoculars 2-5 times daily to record presence and location of the butterflies. From a subsample of 19 trees, each perched butterfly was qualified visually as "cryptic" or "noncryptic" according to Kettlewell's method. The data permitted a basic assessment of the relationship between visitation frequency and background matching. The method scores a lepidopteran as cryptic ("inconspicuous") if the observer fails to separate it visually from its background at two yards or more, and noncryptic if he succeeds in doing so (Kettlewell 1955). The method has "a marked degree of agreement and uniformity" among observers (Kettlewell 1955).

Perch height was estimated visually in relation to reference marks placed $1 \mathrm{~m}$ above ground on all trees. 
To identify factors associated with perch frequency, pertinent variables (listed below) were identified by using an exploratory multiple regression analysis, and then compared with Kruskal-Wallis ANOVA's. All statistical analyses were repeated after excluding cases with any possibility of counting an individual more than once (the few cases in which a different result was obtained appear here as "purged data").

Species characteristics: The butterflies were Hamadryas amphinome (Lucas, 1853), $H$. februa (Godart, 1824), H. feronia (Fruhstorfer, 1916), H. glauconome (Bates, 1864) and $H$. guatemalena (Bates, 1864). Their wing length is about $4 \mathrm{~cm}$, except for $H$. guatemalena $(4.5 \mathrm{~cm})$. The five species have similar behaviors, hostplants (the euphorbiaceous vines Dalechampia spp.), and wing shapes (Jenkins 1983, Monge-Nájera 1992). They differ in color and pattern. In the study areas, $H$. februa is mostly brownish, $H$. glauconome has a large chalky wing area, $H$. amphinome is bluish, and $H$. feronia and $H$. guatemalena are brown with white and light blue markings, the latter two being difficult to distinguish except for their size (Jenkins 1983, Monge-Nájera 1992). Voucher specimens are in The Natural History Museum, London (No. 1987-269) and in the Invertebrate Museum of the University of Panama, Panama.

To distinguish individual behavior, butterflies were captured whenever possible with nets and individually numbered with quick drying blue enamel. Others were collected with standard traps baited with banana pulp and beer and placed in the forest.

"Interaction" is here defined as "spiral flight of a Hamadryas that was originally perching and another Hamadryas that flew in front of its perch".

Experiments: Response to a model (Tinbergen 1958) was tested with a piece of white cardboard cut to the size and shape of Hamadryas and hung from a stick with a piece of black thread. The model was balanced horizontally (approximately one arc per second) and if there was no reaction (flight towards or away from the model) it was rested on the ground for $5 \mathrm{~s}$ until the next attempt. Two sets of ten tests each were done and then the distance between insect and model was reduced (range 8-0.5 m) and the test repeated.

To test the hypothesis of territoriality (i.e. presence of a resident on the tree reduces the occupancy by newcomers) some perching males were removed to compare the behavior of newcomers with cases in which the resident was not removed. Removed males were marked through the net to reduce manipulation stress and kept there for 20 min or until a new male occupied the tree. Then the net was opened near the tree base to record the behavior of the original occupant.

Hypotheses were tested with nonparametric statistical tests. All data that were not statistically different were pooled for this report (both species and variables); detailed tables are included in Monge-Nájera (1988).

Field recordings and experiments: Field recordings of male sonic emissions (free and tethered individuals) were made in Atenas, Alajuela, Costa Rica with a Sony TC-D5M tape recorder and a Sennheiser MKH 416TV3 monodirectional microphone (power supply: Sennheiser MZA 14T). To test the hypothesis that sound is produced by percussion of the $r$ $m_{1-2}$ veins, without damaging those veins, a piece of cotton was intermittently introduced between them during the upstroke while the tethered butterfly was emitting sound (illustration in final section). Periods without the cotton served as controls. This experimental design was selected after previous tests had shown that (1) a greater reduction in click intensity resulted from using thicker pieces of cotton and viceversa (these were not thick enough to inhibit the full amplitude of wing movement); a piece that measured about $5 \mathrm{~mm}$ in thickness when not 
compressed was appropriate (selected for the experiments described here), (2) sound reduction was highest when the cotton was placed between the $r-m_{1-2}$ veins and the damping effect decreased as the cotton was moved towards the tip or base of wing, (3) the animals continued clicking after experimental rupture of the main forewing vein and both circular wingbase membranes (illustrated and named "hearing membrane" and "Vogel's organ" in Monge-Nájera and Hernández 1993), (4) normal clicking continued if the cotton was introduced among the $r-m_{1-2}$ veins during the downstroke, and (5) similar results were obtained if a piece of synthetic sponge was used instead of cotton (cotton was preferred because it is easier to mold out).

The recordings were digitized and analyzed with the program MacRecorderFarallon, with a lineal resolution of 8 bits and a sampling speed of $11 \mathrm{kHz}$.

Analysis of wing motion and ultrastructure: To measure time between clicks, noise at $60 \mathrm{~Hz}$ and its harmonics were reduced with a digital high-pass filter centered around $3 \mathrm{kHz}$.

Wingbeat frequency and velocity of wings were measured from a photograph of a tethered $H$. feronia, by illuminating with natural light and a flash. As a result, a crisp record (flash) of the wing features and a cumulative record of the moving wing (longer exposure of natural light) in known time were recorded simultaneously on the film. Wing speed was measured by tracing the distance moved and dividing it by the total exposure time (1/250 s).

For the ultrastructural analysis, 97 individuals of eight species were studied, as follows: Hamadryas februa (5 females, 30 males), $H$. feronia ( 2 females, 5 males), $H$. guatemalena (1 female, 8 males), $H$. glauconome ( 1 female, 1 male), $H$. amphinome (1 female, 1 male), S. stelenes ( 2 females, 24 males), A. fatima ( 3 females, 11 males) and $E$. thecla (2 males). E. thecla and two specimens of $H$. februa from a population which does not emit audible sound (Otero 1987 pers. comm.) were from NE Venezuela, the rest are from central Costa Rica.

Specimens were fixed in KAAD for at least a week and preserved in $75 \%$ ethanol. Scales and debris were eliminated with a brush and by manual or ultrasonic agitation while submerging the body ( $6 \mathrm{~min})$ and the wings ( 3 min) in commercial bleach (approximately $2.5 \%$ sodium hipochlorite). After a rinse in distilled water, the specimens were dried with the help of a vacuum evaporator or in the air. Observations were done with a scanning electron microscope.

\section{RESULTS}

Natural history of Hamadryas perching behavior. The butterflies perched or "alighted" on tree trunks and branches. Almost all perching individuals were males, and they appeared to use the trees as courting territories (Monge-Nájera 1988). They are cryptic on grayish and brownish bark, and on bark covered by gray lichens. Individuals entering urban areas perch on gray or brown walls of a variety of materials. They normally apress them to the surface and hold their wings in planiform position (sensu Scoble 1992, see Young 1974). On windy days the wings may flap slightly but that is not visible beyond a few centimeters. On hot sunny days the wings may briefly be held elevated or even in a veliform position (sensu Scoble 1992).

Perching and tree species. Almost all individuals that perched in the study sites were males. Thus, these results and the discussion apply to them. Considering the number of available trees of each species, $H$. feronia perched more frequently than expected on Luehea seemani in Site 1, and Psidium guajava and Luehea sp. in Site 2; H. februa 
aligned most often on $S$. purpurea in both countries; $H$. amphinome on Mangifera indica, $H$. guatemalena on Psidium guajava and $H$. glauconome on Hymenaea courbaril and Bursera simaruba (Table 1).

Relative use by site, and effect of several factors: More butterflies were counted at Site 1 , followed distantly by Site 2 and Site 3 (Tables 1 and 2, Appendix 1).

Sites 1 and 2 were visited by $H$. amphinome, $H$. februa and $H$. feronia and all perched on the trees (Table 1). In Site 3 the perching butterflies were $H$. februa, $H$. glauconome and $H$. guatemalena (Table 3 ). Butterfly species differed by site and among themselves in use frequency (Kruskal-Wallis $\mathrm{p}=0.0148$ for site and $\mathrm{p}=0.0001$ for species). Hamadryas feronia was the most frequently recorded species in sites 1 and 2 and $H$. guatemalena in Site 3 (Tables 2-3, Appendix 1).
The butterflies perched more often on some individual trees and did not use others during the study period (Figs. 1-3). General tree trunk ("background") color was associated significantly with tree use (Kruskal-Wallis $\mathrm{p}=0.0030$ ).

Perching was more frequent on backgrounds rated as cryptic ( $\mathrm{N}=60$ records): in 14 trees where perching frequency was low (0-8 records), only $60 \%$ of sighted butterflies were considered "cryptic on the background", in four trees with $15-20$ records, $72 \%$, and in the most used tree (117 records), $81 \%$ (see Materials and Methods).

On the other hand, at Site 3 (where more variables relating to the trees were recorded), presence of food and mud, and position of trees in intersection sites along flight routes, tree diameter and height, as well as lichen cover, bark texture and bark basal color did not have significant effects ( $p>0.47$ or higher).

TABLE 1

Tree perching by Hamadryas butterflies: total number of trees observed, count of butterflies perching on each tree, and number of trees of each species used by the butterflies to perch, in two Panama sites. Each row corresponds to a tree species. (For taxonomic authorities see Monge-Nájera 1988)

Butterfly species

Site and tree species

\begin{tabular}{lc}
\multicolumn{2}{c}{ H.februa } \\
Trees $\quad$ Butterflies \\
used $\quad$ perching
\end{tabular}

\begin{tabular}{lcc}
\multicolumn{2}{c}{ H. amphinome } & \\
Trees & Butterflies & Trees \\
used & perching & used
\end{tabular}

Site 1

Guazuma ulmifolia Spondias purpurea Luehea seemani Mangifera indica Cecropia sp.

Site 2
Guazuma ulmifolia
Luehea sp.
Mangifera indica
Psidium guajava
Palmae
Unidentified

$H$.
Trees
observed
17
7
2
2
5
1

54
2
14
2
3
1
32


TABLE 2

Tree perching by Hamadryas butterflies: total number of trees observed, count of butterflies perching on each tree, and number of trees of each species used by the butterflies to perch, in Costa Rica. Each row corresponds to a tree species

Butterfly species

Tree species

Site 3

Guazuma ulmifolia

Spondias purpurea

Psidium guajava

Eugenia salamensis

Bursera simaruba

Cedrela mexicana

Hymenaea courbaril

Rollinia sp.

Cordia alliodora

Entherolobium ciclocarpum

Zanthoxylum sp.

Casearia aculeata

Anacardium excelsum

Pithecolobium sp.

Tabebuia rosea

Persea americana

Inga sp.

$\begin{array}{ccc}\begin{array}{c}\text { Trees } \\ \text { observed }\end{array} & \begin{array}{c}\text { H.guatemalena } \\ \text { Butterflies } \\ \text { perching }\end{array} & \begin{array}{r}\text { Trees } \\ \text { use }\end{array} \\ 43 & 37 & 7 \\ 6 & 2 & 2 \\ 1 & 0 & 0 \\ 6 & 21 & 1 \\ 3 & 0 & 0 \\ 12 & 2 & 1 \\ 1 & 0 & 0 \\ 1 & 9 & 1 \\ 1 & 0 & 0 \\ 1 & 0 & 0 \\ 2 & 2 & 1 \\ 1 & 0 & 0 \\ 1 & 0 & 0 \\ 1 & 0 & 0 \\ 1 & 0 & 0 \\ 2 & 0 & 0 \\ 1 & 0 & 0 \\ 2 & 1 & 1\end{array}$

\begin{tabular}{cr}
\multicolumn{2}{c}{ H.glauconome } \\
Butterflies & Tree \\
perching & used \\
19 & 7 \\
1 & 1 \\
0 & 0 \\
1 & 1 \\
0 & 0 \\
7 & 2 \\
0 & 0 \\
7 & 1 \\
0 & 0 \\
2 & 1 \\
0 & 0 \\
0 & 0 \\
0 & 0 \\
0 & 0 \\
0 & 0 \\
0 & 0 \\
0 & 0 \\
1 & 1
\end{tabular}

Vertical distribution: Vertical distribution of perches varied significantly. $H$. guatemalena and $H$. februa represent a low-perching group (means under $3 \mathrm{~m}$ ) (Fig. 4); H. feronia and $H$. glauconome also perch at similar heights (middle group, around $3 \mathrm{~m}$ ); H. amphinome has the highest perches and the greater range and variance (mean $5.4 \mathrm{~m}$ ). Members of each height group do not differ among themselves, while both groups differ among themselves and from $H$. amphinome (Kruskal-Wallis ANOVA and Tukey's Test, p<0.01). Populations of $H$. februa perched at the same heights in both countries.

The perching height of $H$. feronia is related to time of day (Kendall Tau, $\mathrm{p}<0.01$ ). Before $1700 \mathrm{~h}$, many perch less than $2 \mathrm{~m}$ from the ground, after that time, most perch above that height (Fig. 5). Species from all heights have underside eyespots and a similar wing length.

Hamadryas perch chiefly on trunks in Site 1 and more on branches in the other sites (Kendall Tau, $\mathrm{p}<0.01$, percentage on branches:
$18 \%$, Site 1; 65\%, Site 2; 65\%, Site 3). The relative use of branches and trunks is not related to the time of day (Kendall Tau, $\mathrm{p}>0.05$ ).

Cardinal point distribution: The south and the east are more used in Site 1, there is a west preference in Site 2, and the east is more used in Site 3 (Kendall Tau, p<0.01, Fig. 6).

The use of each cardinal side of the tree is independent of the time of day (Kendall Tau, $\mathrm{p}<0.01)$.

No species shows preference for the sunny or shadowed side of trees on overcast days (Kendall Tau, p >0.05); on sunny days, $H$. feronia perches more frequently on the sunny side $(57 \%)$ and the other species do the opposite ( $36 \%$ on sunny side, Pearson Chisquare, $\mathrm{p}<0.01)$.

The proportion of Hamadryas on sunlit perches is independent of the time of day (Kendall Tau, $\mathrm{p}>0.05$ ), except for the pooled 


\section{TABLE 3}

Tree perching by Hamadryas butterflies: number of observed trees, number of butterflies perching on each and number of trees used to perch in Costa Rica, against occurrence of food and mud

Butterfly species

Sites and tree species

With food
With mud
In meeting of tree rows
Not in meeting
Without mud
In meeting of tree rows
Not in meeting
Without food
With mud
In meeting of tree rows
Not in meeting
Without mud
In meeting of tree rows
Not in meeting
Total
With mud
In meeting of tree rows
Not in meeting
Without mud
In meeting of tree rows
Not in meeting

\begin{tabular}{ccccc} 
& \multicolumn{2}{c}{ H.guatemalena } & \multicolumn{2}{c}{ H.glauconome } \\
Trees & Butterflies & Trees & Butterflies & Trees \\
observed & perching & used & perching & used
\end{tabular}

\begin{tabular}{cc}
\multicolumn{2}{c}{ H. februa } \\
Butterflies & Trees \\
perching & used
\end{tabular}

Food: Hamadryas feed on liquids from fermenting fruit.

Mud: for Hamadryas mud is a source of water and possibly also of salts.

Meeting of tree rows: some trees form natural or artificial rows and Hamadryas fly along them. Where two rows meet, the number of passing females is higher and males might concentrate there.

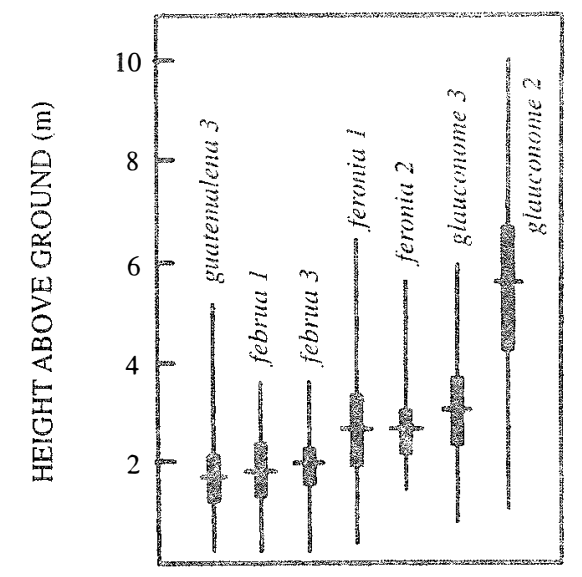

Fig. 4. Perching height of Hamadryas butterflies: range (vertical lines), standard deviation (bars) and mean (horizontal lines). Numbers: study sites (see text) $(\mathrm{N}=436)$.

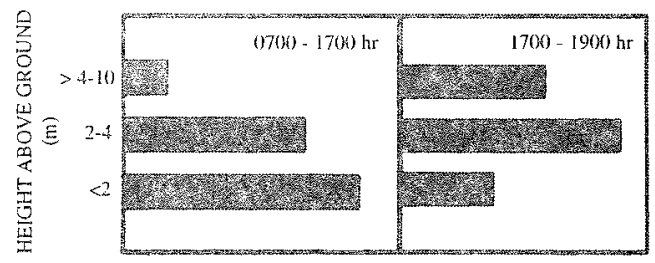

Fig. 5. Perching height of Hamadryas feronia has two significantly different patterns: before and after $1700 \mathrm{~h}$ $(\mathrm{N}=208)$. 


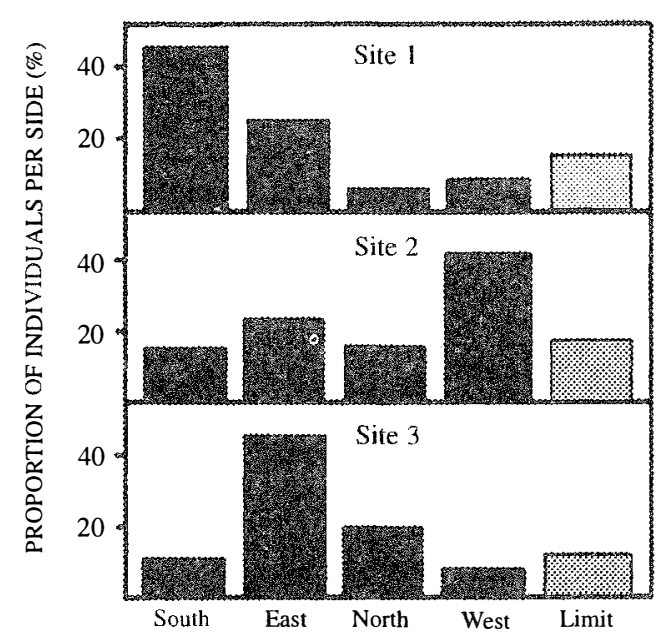

Fig. 6. Cardinal point orientation of Hamadryas spp. in the three sites $(\mathrm{N}=343)$.

("all species") data that show a preference for the shadowed side after 11:00 h (50\% before 11:00 $\mathrm{h} ; 67 \%$ in shadow after 11:00 h).

Posture and seasonality: All species perch with the head downwards $(\mathrm{N}=523)$, parallel to vertical or slightly inclined trunks; when perching on very inclined trunks or on horizontal branches, they align strictly parallel to gravity. Important deviations from that orientation occur during feeding and copulation (pers. observ.).

The height of perches is not seasonal (Kendall Tau, $\mathrm{p}>0.05$ ) unless purged data are used (slight increase in perch height for rainy season, Kendall Tau, $\mathrm{p}<0.05$ ). Similarly, there is no seasonal difference on use of tree parts, cardinal orientation and perch illumination $(H$. feronia, Kendall Tau, $\mathrm{p}>0.05$ ).

\section{Reactions to moving objects:} Hamadryas males generally react when a variety of organisms move in front of their perches (Fig. 7). A flight toward the newcomer -and return to perch- is the most frequent reaction when another Hamadryas enters the field of view. Other stimuli are ignored or

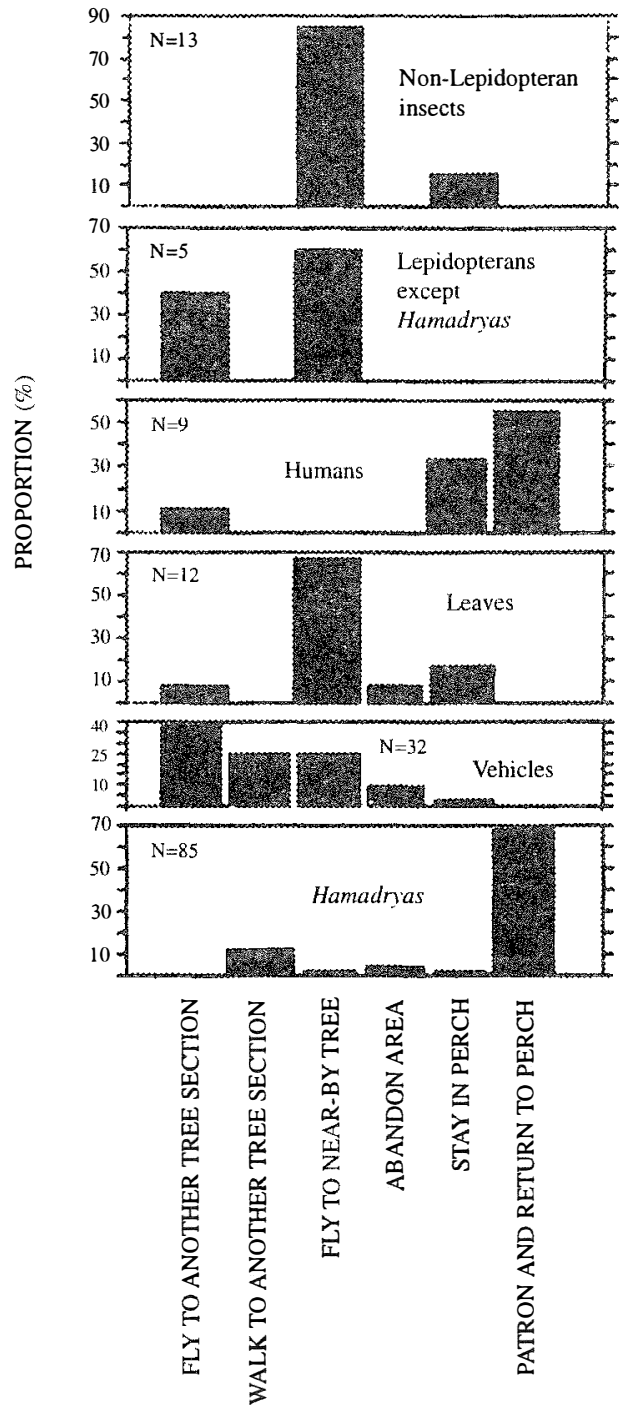

Fig. 7. Reactions of Hamadryas feronia and Hamadryas guatemalena to a variety of stimuli, including falling leaves and human observers. Some perches were on roadside trees, so the reaction to vehicles passing in front of perches was also recorded. $(\mathrm{N}=201)$.

cause desertion of the tree, more often than a change of perch or a flight toward the intruder (Fig. 7, Kendall Tau, p < 0.01)

Experiments with cardboard models: Response to cardboard model varies with the 
species, both for distance (Kendall Tau, $\mathrm{p}<$ $0.01, A=4.1-8 \mathrm{~m}, \mathrm{~B}=4 \mathrm{~m}$ or less) and sequence of model presentation (Kendall Tau, $p<0.01$; $\mathrm{C}=$ first six presentations, $\mathrm{D}=$ presentations 7 th_ $^{\text {th }}$ $46^{\text {th }}$ ). H. guatemalena reacted (i.e. flew toward model instead of ignoring it) more frequently when the model was far (A 14\%, N=43; B=3\%, $\mathrm{N}=130$; Pearson's Chi-square, $\mathrm{p}<0.01)$ and less frequently $(\mathrm{C}=11 \%, \mathrm{~N}=69 ; \mathrm{D}=4 \%, \mathrm{~N}=104$; Pearson's Chi-square, $\mathrm{p}<0.01)$ at the end of each session of ten consecutive tests. On the contrary, $H$. februa reacted only if the model was at short range $(\mathrm{A}=0 \%, \mathrm{~N}=8 ; \mathrm{B}=42 \%$, $\mathrm{N}=28$; Pearson's Chi-square, $\mathrm{p}<0.01$ ), independently of the part of the sequence $(C$ $67 \%, \mathrm{~N}=6 ; \mathrm{D}=36 \%, \mathrm{~N}=30$; Pearson's Chisquare, $\mathrm{p}<0.01)$. Distance and sequence appeared to be unimportant for $\mathrm{H}$. glauconome (A $50 \%, \mathrm{~N}=6 ; \mathrm{B}=50 \%, \mathrm{~N}=12 ; \mathrm{C}=50 \%, \mathrm{~N}=6$; $\mathrm{D}=50 \%, \mathrm{~N}=12$; Pearson's Chi-square, $\mathrm{p}>0.05$ for both) but the sample was small.

Experimental removal of resident males: When resident males were removed, $82 \%$ of the trees were occupied by newcomers within $20 \mathrm{~min}(\mathrm{~N}=26)$, but only $2.5 \%$ of trees were occupied if the resident was present $(\mathrm{N}=80)$ (Chi-squared test, $\mathrm{p}<0.001$ ). In five out of 26 cases, the original resident participated in noisy aerial interactions with the new occupant, but mostly it flew to a different tree or stayed in the net after it was opened (see methods section for details). Manipulated males did not recover trees during the observation period ( $1 \mathrm{~h}$ after release) and often perched with the head pointing upwards.

Result of natural interactions: Most spiral flights involve individuals of one species, but occasional inter-specific flights with sound (intra-generic) and without sound (extrageneric) were also observed. Such encounters are rare and the small sample (Table 4) might account for the lack of correlation between result (resident abandons or retains perch) and the taxonomic relation of the participants (Kendall Tau, $\mathrm{p}>0.05$ ).
TABLE 4

Results of aerial interactions of two species of Hamadryas with members of the same species ("intra-specific"), with Hamadryas of a different species ("intra-generic") and with lepidopterans of other genera ("inter-generic"). The tree resident flies towards another that moves in front of its perch. After the aerial interaction, one or both individuals can stay in the tree or abandon it $(N=32)$. All under natural conditions.

Type of interaction

$\begin{array}{lccc}\text { Species and result } & \begin{array}{c}\text { Intra- } \\ \text { specific }\end{array} & \begin{array}{c}\text { Intra- } \\ \text { generic }\end{array} & \begin{array}{c}\text { Inter- } \\ \text { generic }\end{array} \\ \begin{array}{l}\text { H. guatemalena } \\ \text { Only one stays }\end{array} & 4 & 8 & 1 \\ \text { Both stay } & 7 & 2 & 0 \\ \text { Both abandon } & 1 & 0 & 0\end{array}$

H. glauconome

Only one stays

Effect of time on interactions: Each marked $H$. feronia male was seen perching on 1-4 trees daily, without difference between seasons (rainy season 1.93 trees/day, $\mathrm{N}=29$, dry season 1.45 trees/day, $\mathrm{N}=20$, Mann Whitney Wilcoxon, $\mathrm{p}>0.05$ ). Each tree used had a minimum daily mean of 1.62 residents in the rainy season $(\mathrm{N}=108)$ and 1.41 in the dry season $(\mathrm{N}=76)$. There is no difference in number of residents between seasons if all used trees are counted (Mann Whitney Wilcoxon $p>0.05$ ), but there is a difference between the "preferred" (five most used) trees and the rest (1.91 residents/day, $\mathrm{N}=82$ and 1.21 residents/day, $\mathrm{N}=102$, respectively, Mann Whitney Wilcoxon, $\mathrm{p}<0.01$ ).

After interactions ( $\mathrm{N}=80$ ), newcomers left the trees and the residents returned to their perches in $85 \%$ of the cases. Twice the newcomer took the perch and the other individual left.

Most $H$. feronia interactions occur from 13:00 through 15:00 hours and are more frequent in the rainy season (Mann Whitney 
Wilcoxon, $p<0.01$, Fig. 8). No signs of aggression were seen at night, when males perch in groups hanging with wings closed on the back from underneath leaves on branch tips. In Site 1 four males used the same tree to spend the night; they flew to the leaves in a very specific period, between $18: 25$ and 18:35 (same as in captive $H$. februa, pers. obs.).

Sound-producing mechanism: The experimental intromission of soft material (cotton) between the $r-m_{1-2}$ veins during wing clapping significantly reduced the intensity of the click sounds, which were produced normally when the cotton and rod were removed (Fig. 9). This procedure indicated that the $r-m_{1-2}$ veins are percussive and allowed us to intermittently silence the butterfly at will ( $\mathrm{N}=396$ claps, 153 with cotton and 243 controls for two H. februa, and $\mathrm{N}=462,217$

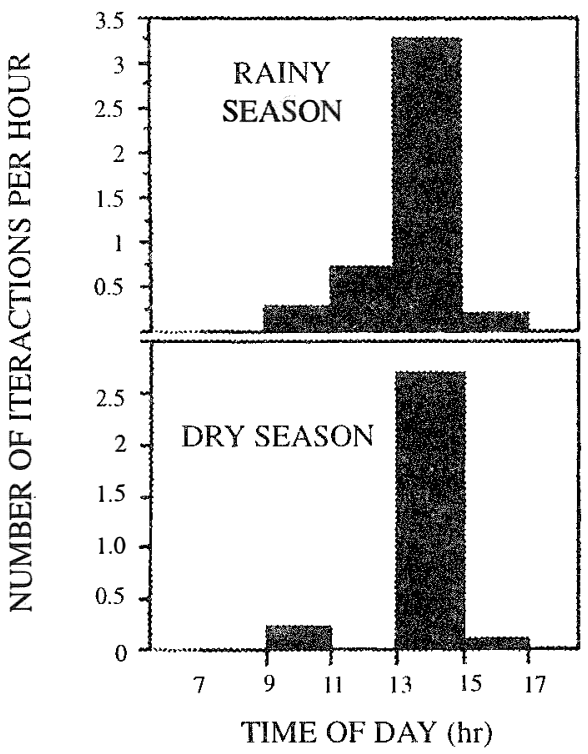

Fig. 8. Aerial interactions/hour by time of day and season, Hamadryas feronia $(\mathrm{N}=89)$.

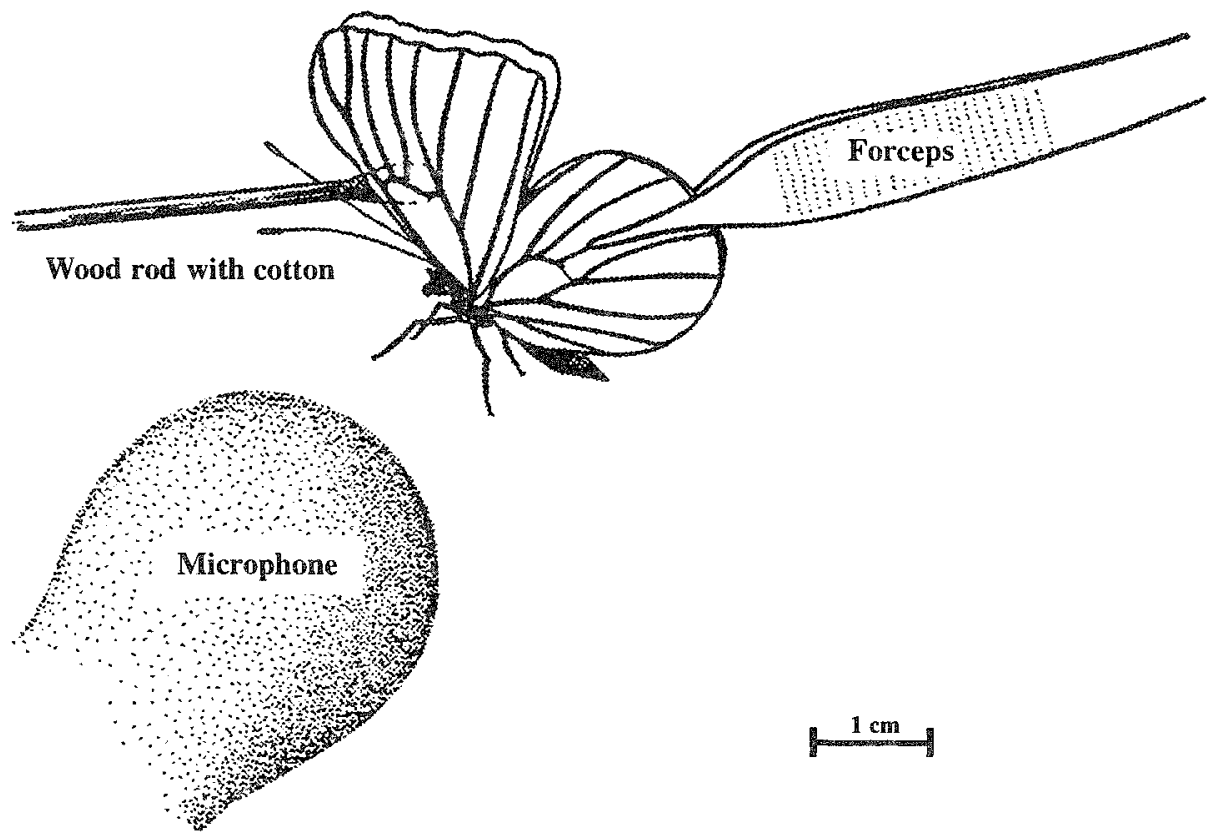

Fig. 9. Experimental procedure. A piece of cotton attached to a wood rod was intermittently introduced between the veins hypothesized to produce the sound. Sound intensity varied with cotton thickness, and normal clicks were produced when the cotton was removed. 
cotton, 245 controls for two $H$. feronia). The physical analysis of some representative tests appears below.

Wing movements: Each click was emitted at the end of the wing's upstroke movement. At the final part of the cycle, both wings become slightly curved longitudinally (Fig. 10A). Shortly before the clap the wings are almost straight (Fig. 10B) and meeting begins at the distal extreme (Fig. 10C). As the contact area increases downward the $r-m_{1-2}$ veins collide producing the click and then the wings move apart. There is a marked longitudinal bend of the wings slightly above the $r-m_{1-2}$ veins (Fig. 10D). In both upstroke and downstroke the hind margins of each wing pair appear to move ahead of the fore margins (Figs. 10 A-D). It is unknown if clapping also occurs in nature at the end of the downstroke, but it can be seen in tethered individuals and no sound is produced.

Wingbeat frequency $(\mathrm{Hz})$ measured from the photograph was 11 in $H$. feronia, and according to the sound analysis (below), 10.80 $\pm 3.37(5.81-21.05 ; \mathrm{N}=67)$ in tethered $H$. feronia and $23.45 \pm 2.41(20.00-28.57 ; \mathrm{N}=26)$ in a free-flying $H$. amphinome.

The velocity of the wing at the apical spot is $2100 \mathrm{~mm} / \mathrm{s}$ (Fig. 10), while the heavier mid part of the wing, which contains the percussive veins, moves at a lower speed of $1420 \mathrm{~mm} / \mathrm{s}$.

Sound characteristics: When some expected clicks are missing in a sequence, the distance between produced clicks preserves the expected interval (Fig. $11 \mathrm{~A}$ ). This suggests that missing clicks represent cases in which the wings moved at the normal speed but were not clapped.

The effect of the soft material in reducing click intensity is obvious not only to the human ear but also in sonograms (Fig. 11).

Overall, clicks last mean $1.38 \pm$ SD 0.45 (min. 0.70-max. 2.40) $\mathrm{ms}(\mathrm{N}=21)$ and the intervals $43.74 \pm 6.05 \quad(32.50-53.20) \mathrm{ms}$ $(\mathrm{N}=26)$. Component click frequencies concentrate around $2.4 \mathrm{kHz}$ (Fig. 11).

Ultrastructure of wing distal half: The sound apparatus is located in the mid-frontal area of the forewings (Fig. 12). A comparison of sound-producing and silent nymphalids shows some clear differences. The transversal veins of $R_{3+4+5}$ and $M_{2}\left(r-m_{1}\right.$ and $\left.m_{1}-m_{2}\right)$, well defined only in Hamadryas, are thicker in males (Figs. 13-14), with the exception of $H$. februa, in which they are thin in both sexes and in the Venezuelan subspecies (Fig. 14). In Hamadryas, the $\mathrm{r}-\mathrm{m}_{1-2}$ veins are devoid of scales and are connected to the $\mathrm{R}+\mathrm{Sc}$ veins in one end, and to the $\mathrm{Cu}$ in the other (Fig. 12).

Ultrastructure of wing basal half: The swollen Sc vein is present exclusively in Hamadryas; it has a serpentine structure inside (Fig. 18). Similar but less developed structures occur also in the $\mathrm{Cu}$ and $\mathrm{A}$ veins. As a result, the percussive $r-m_{1-2}$ veins are connected to a system of three tubes-within-tubes that resemble a resonance box (Fig. 18).

All Hamadryas have a membrane, shaped as an elongated cupola, in the costal cell, here called MCC (membrane of costal cell, Figs. 15-16, 18 B).

Vogel's organs (Figs. 15-17) are well developed in fore wings of all species and occur in both sexes (not studied in A. fatima). This organ (Vogel 1912) occupies the base of $\mathrm{Cu}$ and its rear basal part contacts the base of $\mathrm{A}$, it has a rigid cap (can be broken with a needle) mounted on a flexible ring. There are four chambers under the cap (Fig. 17); ink injected in them does not reach the adjoining veins, suggesting lack of an open connection. The cavity beside Vogel's organ is covered by a large amount of small papillae (Fig. 17).

Production of sound in the field: The emission of sound during joint spiral flights often is part of a male-male intraspecific 

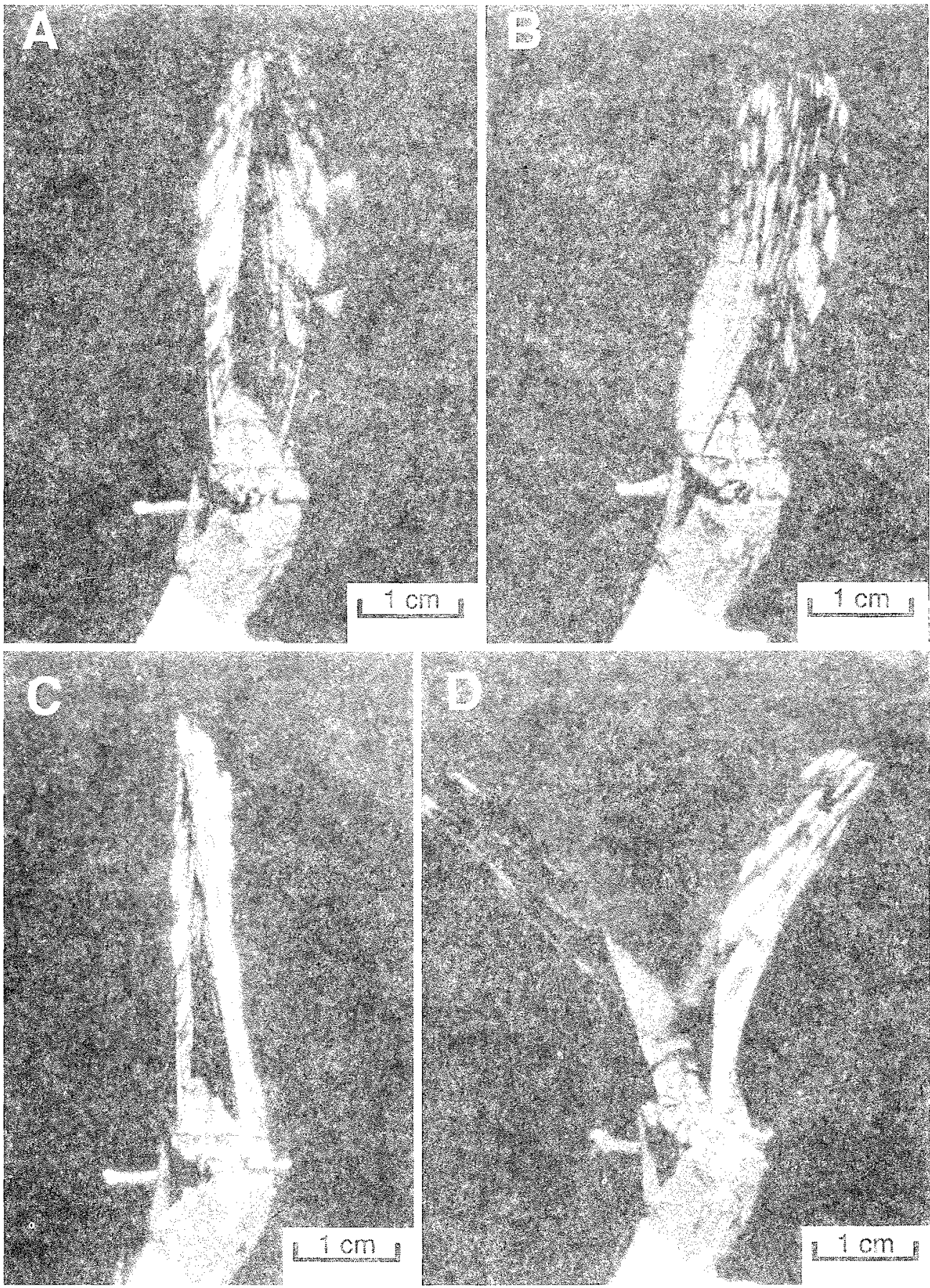

Fig. 10. Sound is produced during vigorotis wingbeating. At the final part of the upstroke movement, both wings become slightly curved iongitudinally (A). Shortly before the clap the wings are almost straight (B) and finally they meet, beginning by the distal extreme $(\mathrm{C})$. The $\mathrm{r}-\mathrm{m}_{1}$, veins (lower arow) collide, producing the click, and the wings move apart. There is a marked longitudinal bend of the wing slightly above these veins (D). Upper arrow marks "white spot" used as movement reference. 

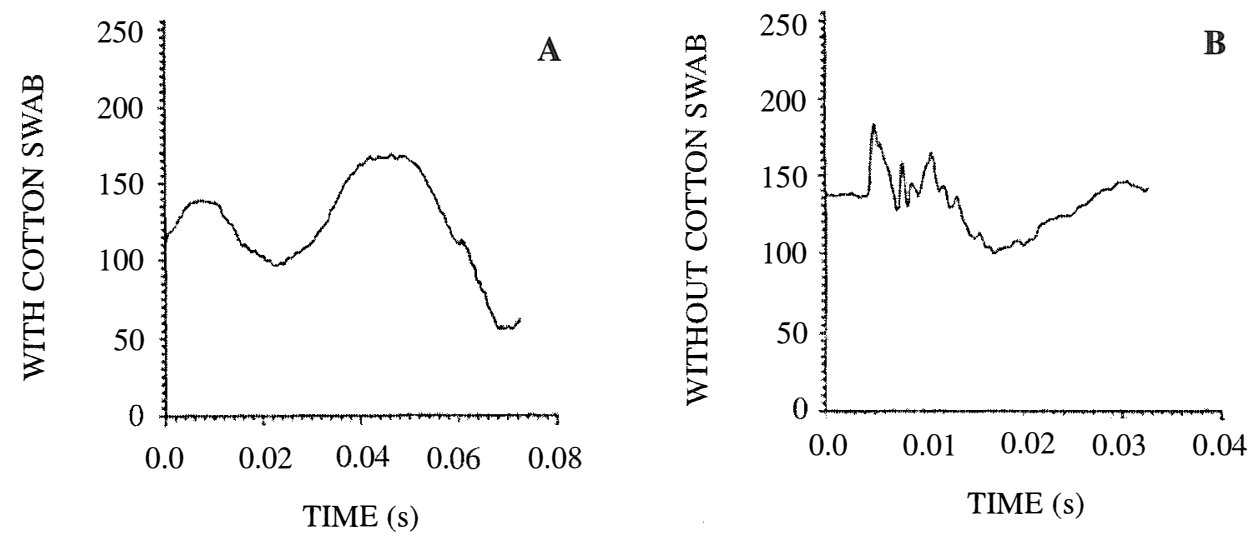

B
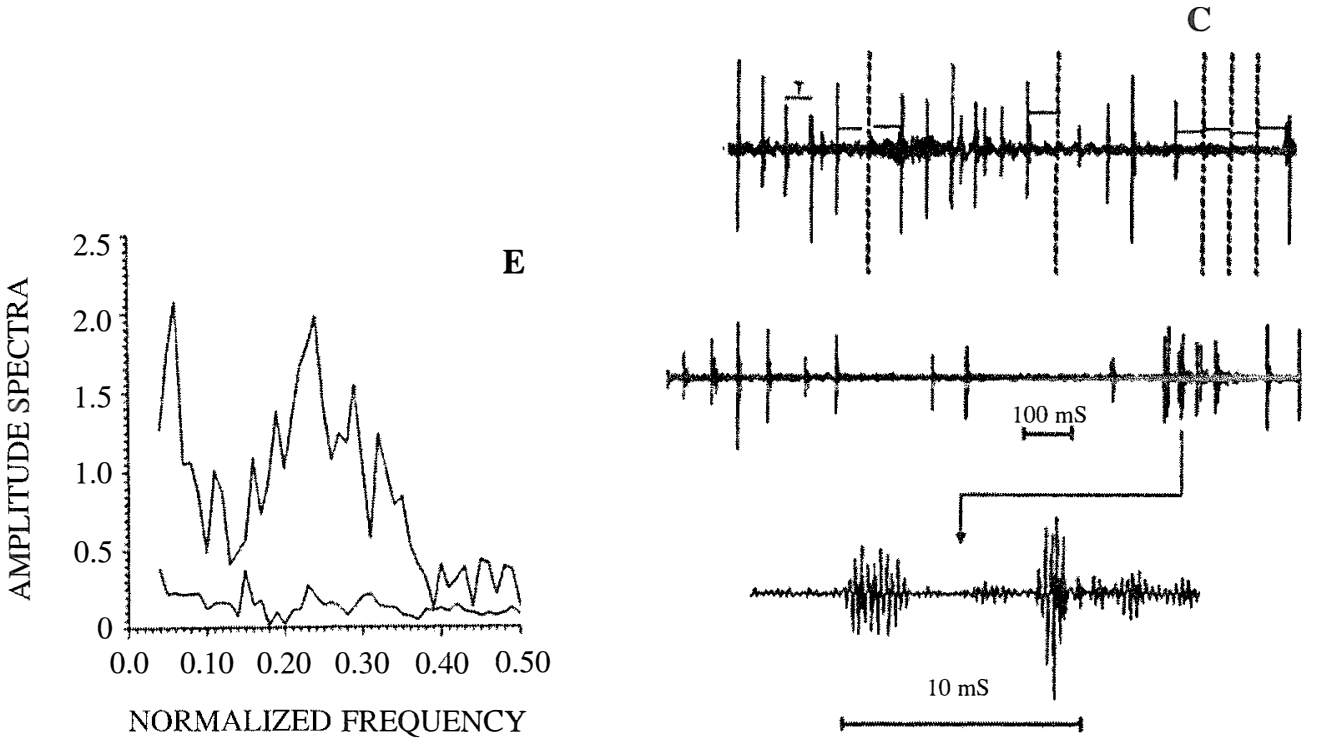

Fig. 11. A, B. The experimental intromission of cotton between the percussive veins decreases the intensity of the clicking sounds. This is audible to the human ear and also shows in the sonogram. C. When some expected clicks are missing in a sequence, the distance between produced clicks preserves the expected intervals (T). Apparently the insect controls the emission of sound by changing wing movement: to click, the wings are clapped. D. When 2-3 individuals interacted, the intervals diminished, suggesting that several individuals were simultaneously emitting sound (detail enlarged). E. The peak amplitude of the click occurs at frequencies of $1.3-3.8 \mathrm{kHz}$. Amplitude in arbitrary units for all figures. For the amplitude spectra: above: signal, below: noise.

interaction (Kendall Tau, $\mathrm{p}<0.01$, Figs. 19 and 20). Exceptionally, we heard sound when we approached the butterflies as well as when they interacted with Satyrinae, apparently in agonistic encounters for food (fallen fruit) as well as in the courtship of $H$. feronia. Females of this species can emit sound when captured (JMN pers. observ. 1995). The sound apparatus exists in both sexes, but may be slightly larger in males (Figs. 13 and 14)

Although severe wing damage is not rare in wild Hamadryas males, the part of the wings that contains the sound system was intact in all of the hundreds of specimens which we have seen (Fig. 21). 


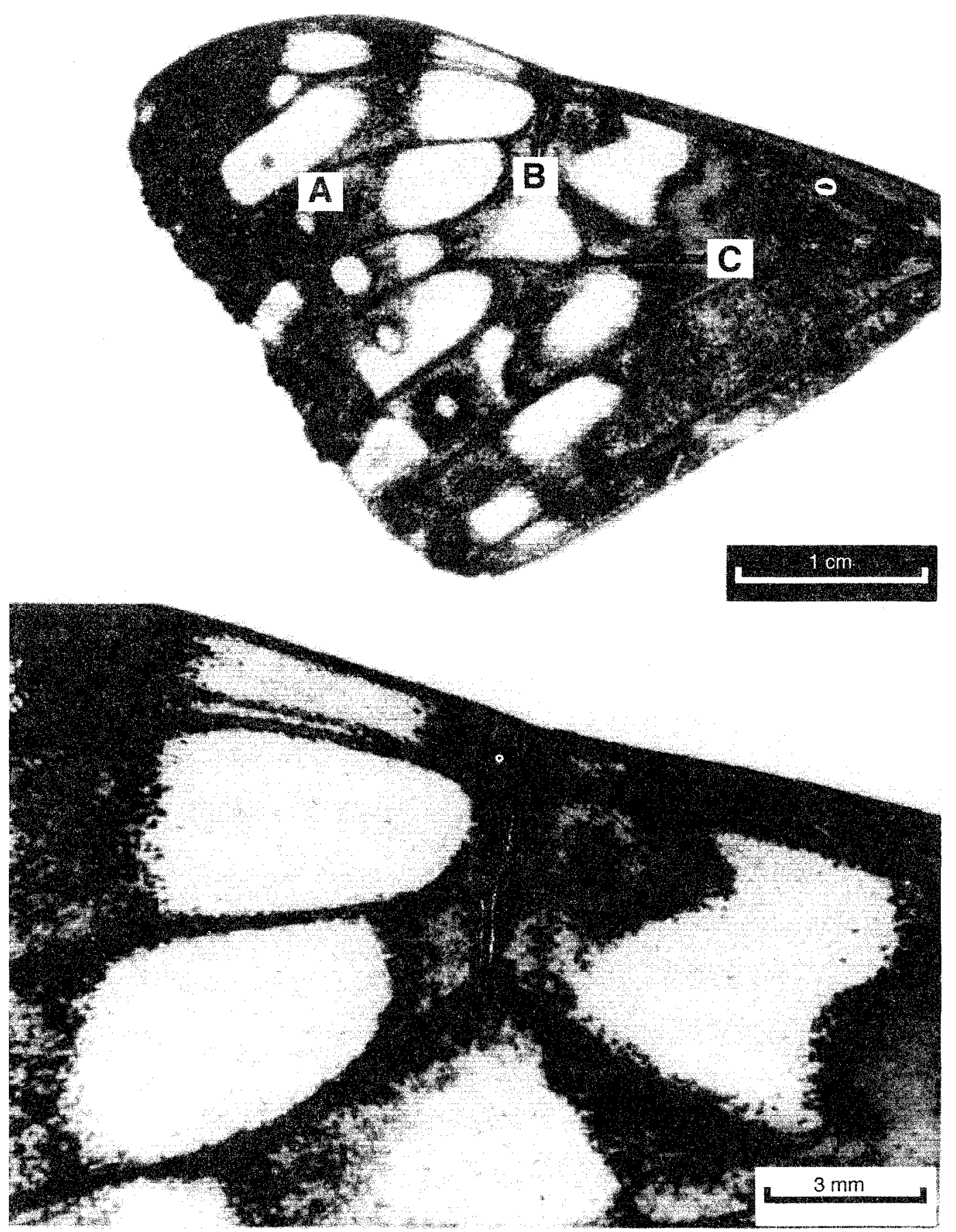

Fig. 12. The percussive part of the sound apparatus is located in the mid frontal area of the forewing (B, detail below). Damping effect decreases as the cotton is moved towards areas A and C. 


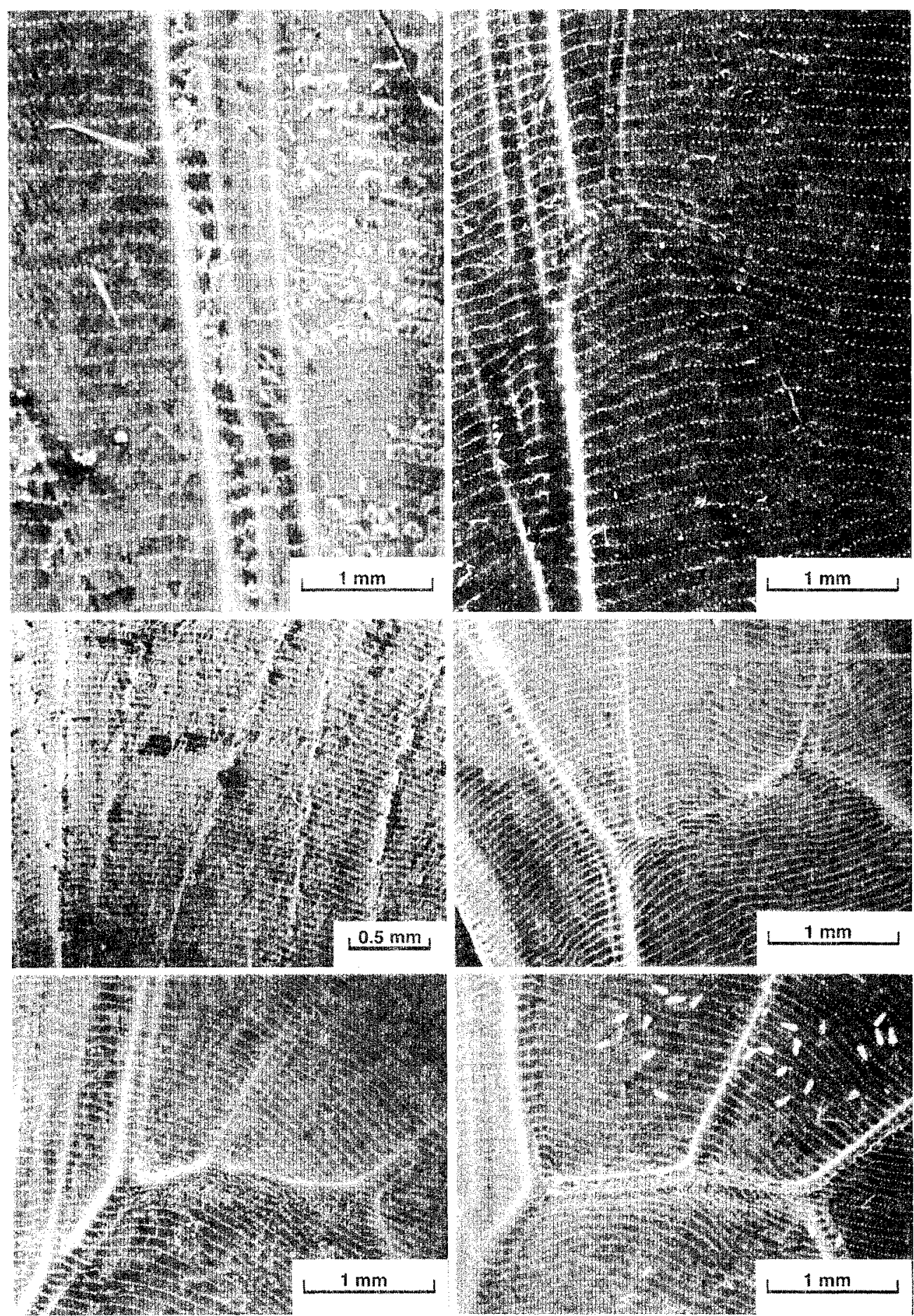

Fig. 13. Forewing veins in Siproeta stelenes (above, left male, right female), male Ectima thecla (middle left), male Hamadryas glauconome (middle right) and Hamadras guatenalena (below: left female, right male) 

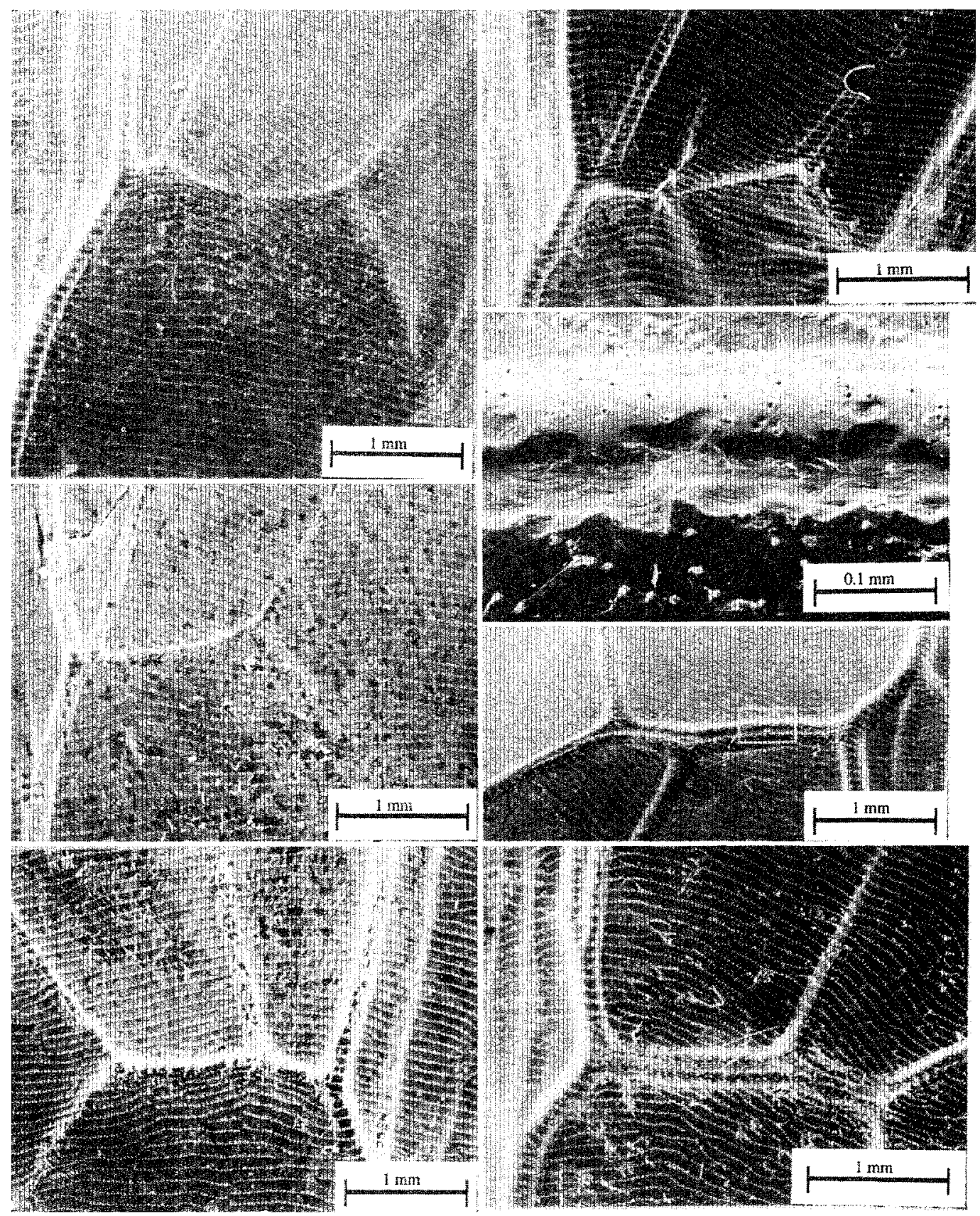

Fig. 14. Forewing veins in Hamadryas februa from Costa Rica (above: left female, right male) and from Venezuela (middle left). Male Hamadryas feronia $\mathrm{r}-\mathrm{m}_{1}$ and $\mathrm{m}_{1}-\mathrm{m}_{2}$ veins have a longitudinal groove (middle right: section marked in box appears enlarged). Below: venation in female (left) and male (right) Hamadryas feronia. 


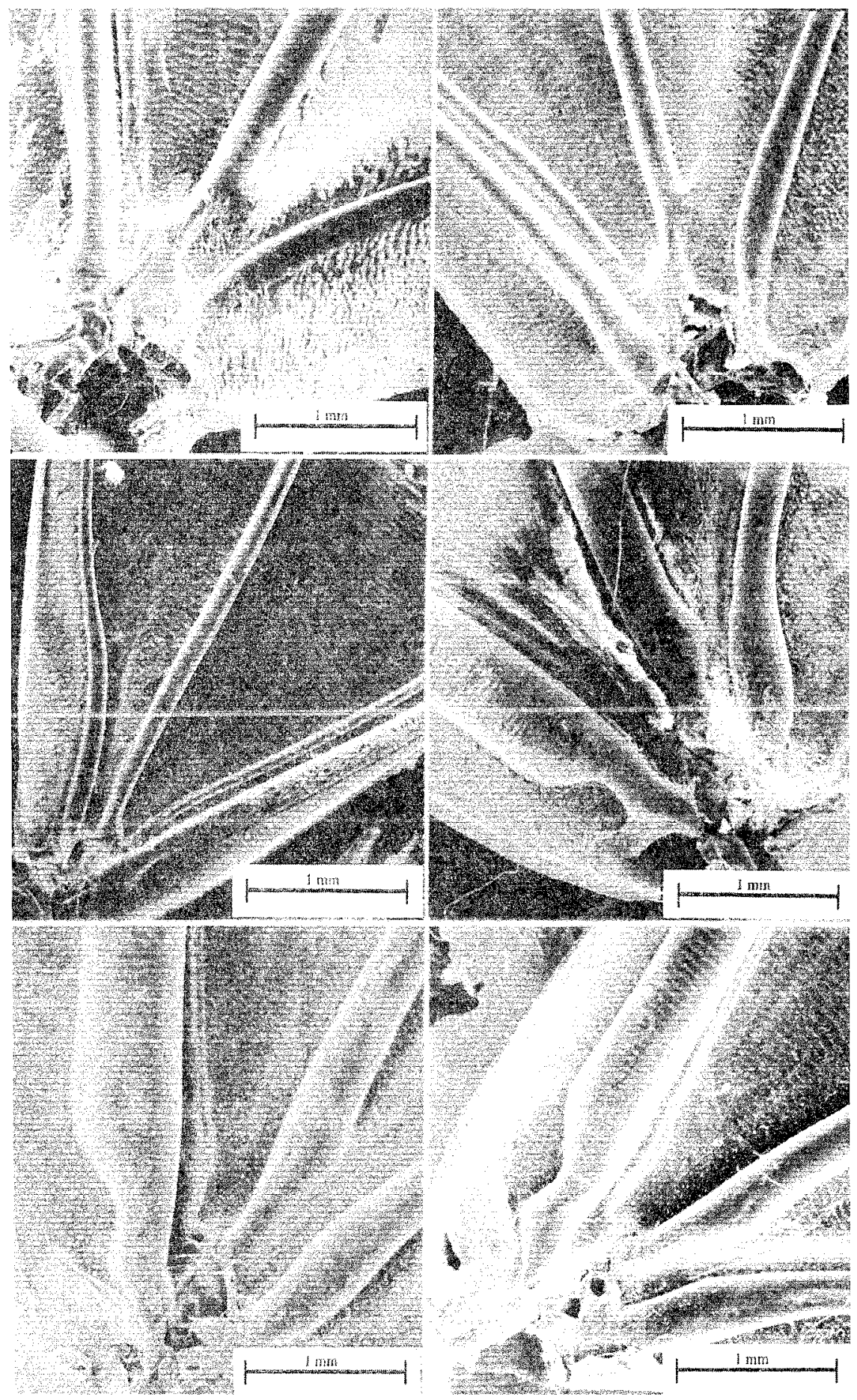

Fig. 15. Base of forewings of Siproeta stelenes (above, left female, right male), male Ectima thecla (middle left), male Hamudryas glauconome (middle right) and Hamadryas guatemalena (below: left female, right male). 


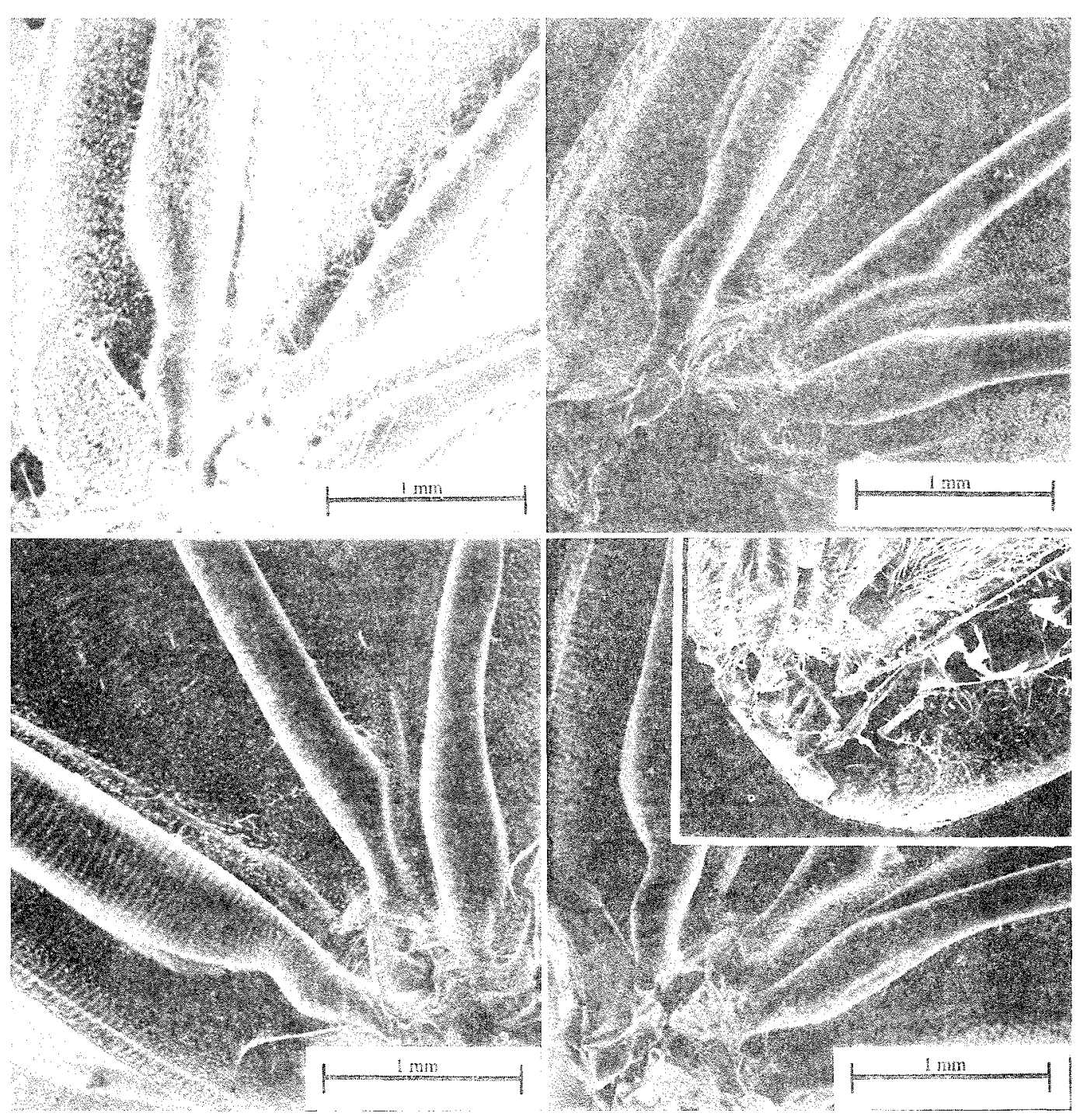

Fig. 16. Base of forewings of Hamadryas feronia (above: Ieft female, right male) and Hamadryas februa (below: left female, right male, with enlargement of Venezuelan specimen by 10X). 


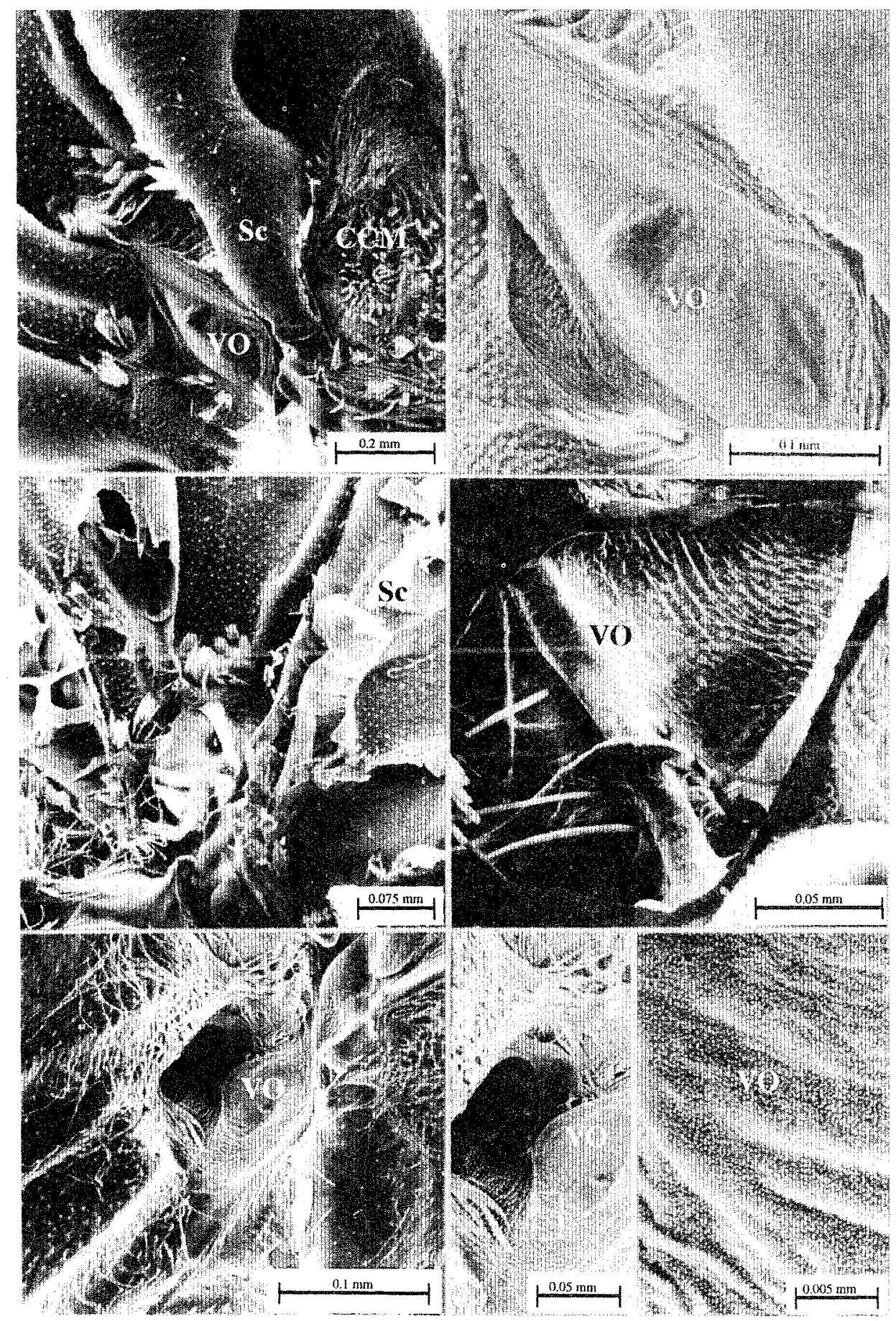

Fig. 17. Details of forewing bases in Hamadryas feronia (above and middle) and Ectima thecla (below) after removal of scales (middle: upper layers removed). VO Vogel's organ, probably a high frequency ear; CCM ear, Sc subcostal vein. 


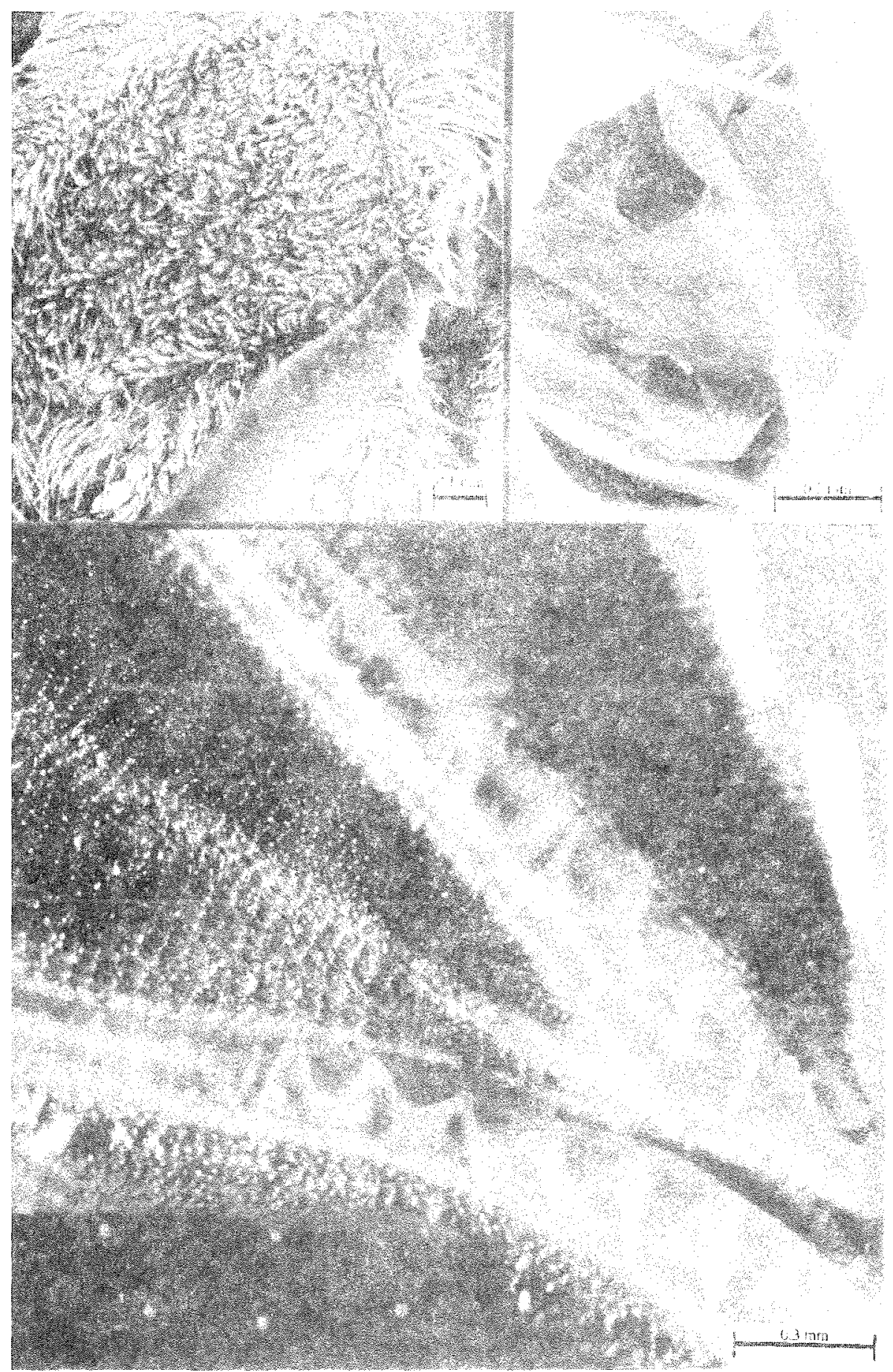

Fig. 18. Details of Hamadryas februa forewings. Below: spiral structure inside veins. Above left: intact ear. Above right: inner view of membranous spiral structure. 


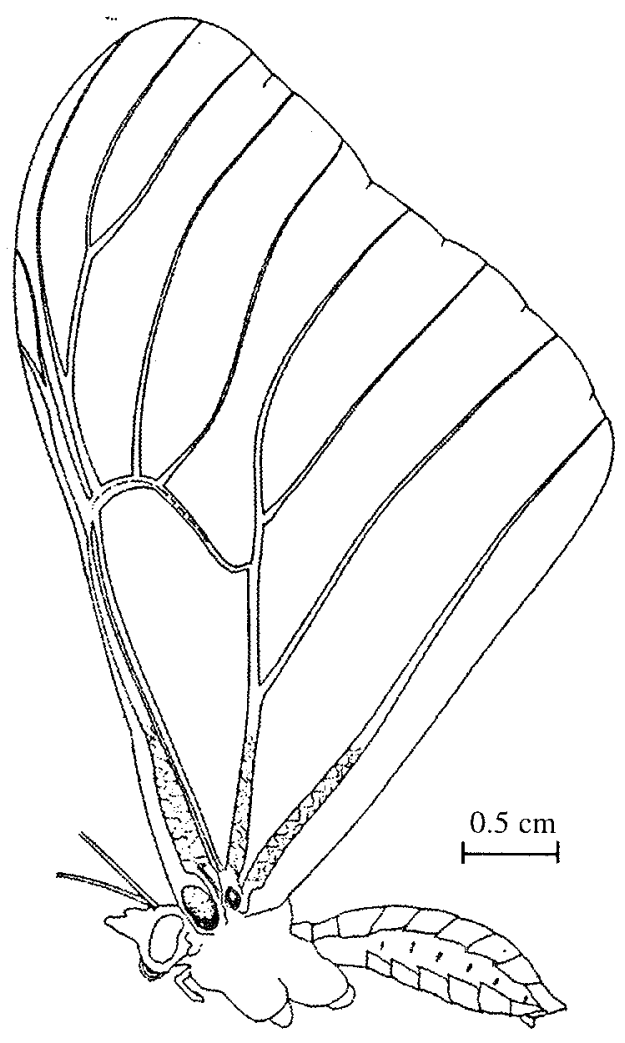

Fig. 19. Reconstruction of Hamadryas wing structure.

\section{DISCUSSION}

Spatial distribution and wing coloration: The widely known case of crypsis in the industrial melanism moth Biston betularia (L.) is controversial because (1) most data are experimental, (2) its natural history is poorly known and (3) the taxonomy of the species is not clear (Keiper 1969, Sargent and Keiper 1969, Sargent 1973, Boardman et al. 1974, Steward 1977a, Sargent 1985).

This study of Hamadryas has the advantage of describing field behavior, and it fits several important requirements not met by the Biston studies: (1) Hamadryas butterflies alight on exposed surfaces and are large enough to be detected and counted with certainty by properly trained and equipped
SOUND PRODUCED (\% CASES)

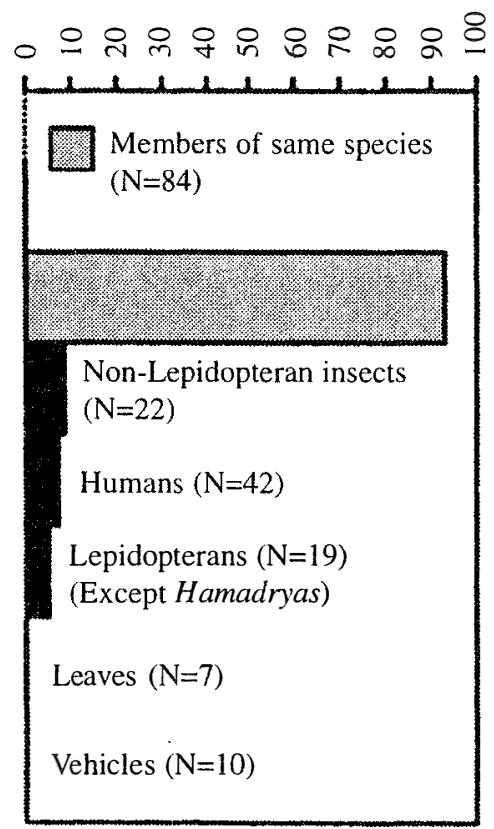

Fig. 20. Production of sound by Hamadryas spp. in response to a variety of stimuli, including falling leaves and human observers. Some perches were on roadside trees, so the reaction to vehicles passing in front of perches was also recorded. $(\mathrm{N}=184)$.

human observers (Jenkins 1983, MongeNájera 1992), (2) their natural behavior continues in the presence of humans (Jenkins 1983, Monge-Nájera 1988), (3) their taxonomy is well established and they can be identified without capture (Jenkins 1983, Monge-Nájera 1992), and (4) their natural history is relatively well known, so factors likely to affect background choice can be identified (Jenkins 1983, Monge-Nájera and Hernández 1991, Monge-Nájera 1992). In this discussion, comparisons are made with cryptic moths because we are aware of no equivalent data for butterflies.

The fact that a few trees of a few species were used frequently as perching sites by the butterflies, while other trees (some of the same species) were never used, is consistent 


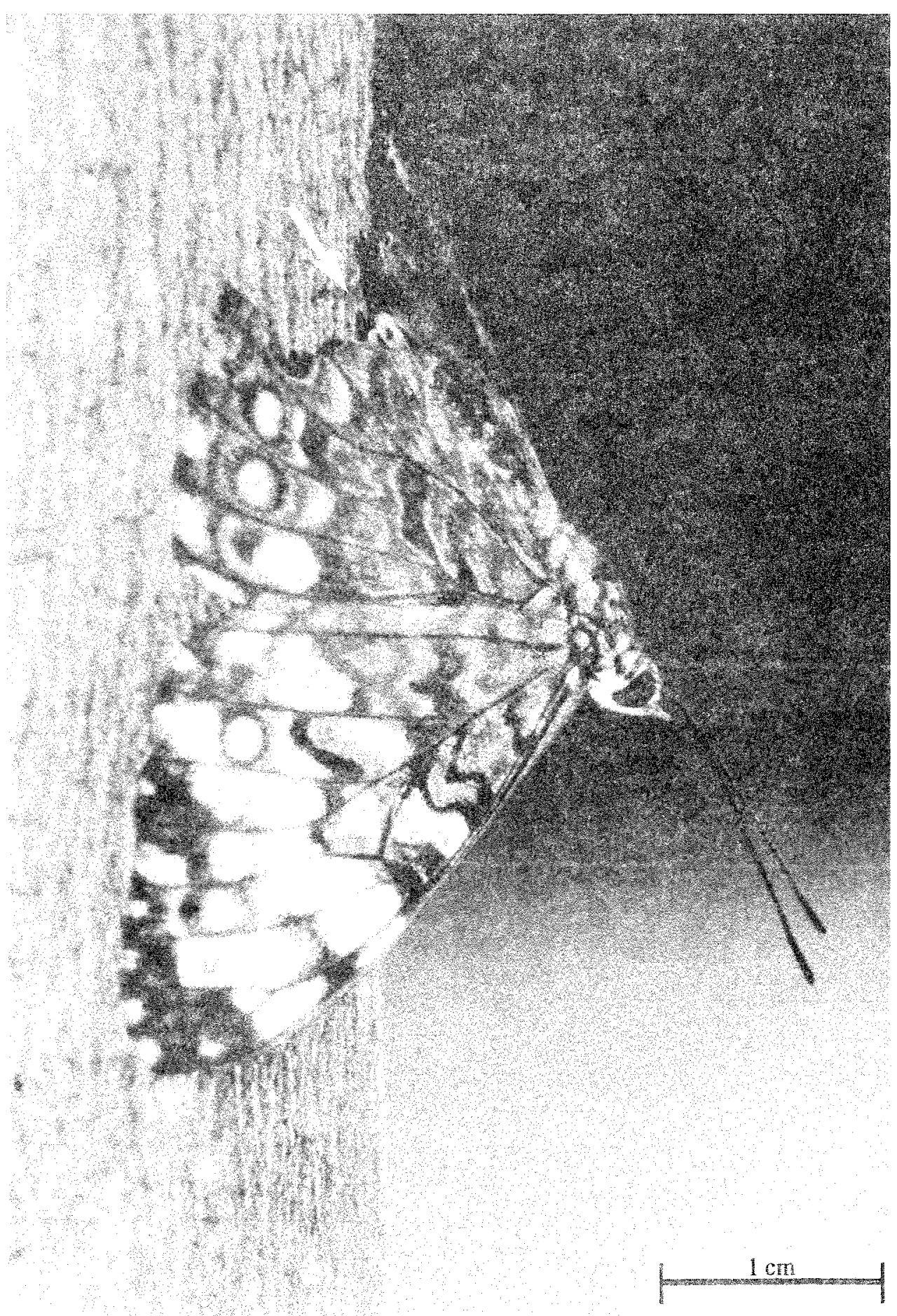

Fig. 21. Severe wing damage (arrow) is not rare in wild Hamadryas males, but the sound-producing section often is in good condition. 
with the hypothesis that certain tree individuals have characteristics that attract Hamadryas males. The underlying mechanism is unknown (see Bitzer and Shaw 1979, Baker 1983, Aiello 1988).

Butterfly species differed by site, possibly because their ability to match trunk colorations in the studied sites differed, as explained under Material and Methods (for details see Jenkins 1983 and Monge-Nájera 1992); for example, the bluish $H$. amphinome perched more frequently on dark bark under thicker canopy (a patch of trees in Site 2, Fig. 2), while light brown $H$. februa perched on light, sun-exposed bark. The significant association between general background color and perching frequency is consistent with the hypothesis that the butterflies actively select backgrounds on which they will be cryptic, in nature.

In our data, background color overrides other possible factors that have been suggested to influence the selection of trees as perching sites: presence of mud where important salts are found, presence of rotting fruit as food (Jenkins 1983, Otero 1988), and position of trees in intersection sites along flight routes used by females (Baker 1972). Hypothetically, males might prefer larger trees that may be visible to females from greater distances, or they may avoid rough bark that could cause wing damage, but neither tree size (measured by diameter and height) nor bark texture were found to be associated with tree use. Probably, lichen cover and bark basal color did not have a significant effect either because they, being mostly greenish or pink, frequently did not match the butterfly colors.

Under natural conditions, Hamadryas butterflies occasionally perch on inappropriate backgrounds, mostly on smooth light brown Psidium guajava trees. The cost of an inappropriate background match seems to be lower than the benefit of obtaining food, which is abundant in the form of rotten fruit that accumulates seasonally under these trees. Under experimental conditions, some moths are known to perch on non-cryptic backgrounds (in 11-64\% of trials) but no explanation has been suggested for the observation (Kettlewell 1955, Steward 1976, 1977b).

This study of Hamadryas has shown that, under natural conditions, these butterflies perch differentially on a variety of backgrounds, that perch selection is associated with background color, and that the backgrounds chosen match wing color, at least to human observers, thus supporting the interpretation that perching choice in Hamadryas has been influenced by natural selection for crypsis. These results fit the theory associated with industrial melanism without having the methodological problems of the Biston studies.

Vertical distribution: The genus Hamadryas appears particularly suited to compare spatial distribution because of the constancy of life histories among most species. Immatures use the same host plants and adults have identical behaviors and foods (Jenkins 1983, Monge-Nájera 1992). Some ecological displacement is expected to evolve under such circumstances and our basic hypothesis was that spatial distribution would show vertical stratification, believed to favor mating encounters (Daily et al. 1991) and the coexistence of more species.

Several collectors have mentioned that (as also found here) Hamadryas species can be classified in a "lower" group (e.g. H. februa, $H$. glauconome and $H$. guatemalena) and a "higher" canopy group (e.g. H. fornax, $H$. rosandra and $H$. alicia), although there were no quantitative studies previous to the present work (Jenkins 1983).

This study fits the requirements mentioned by De Vries (1988) and found a statistically significant vertical stratification consistent with the "ecological displacement" interpretation, but of course does not prove it. The five species 
perch higher than moths that also are cryptic on bark (Sargent and Keiper 1969). They perch higher at the end of the day possibly to reduce flight distance to the foliage where they spend the night. The relative use of branches and trunks apparently reflects the vertical range of perches typical of each species: trees in Site 1 branched at greater height and thus more butterflies perched on the trunks.

Cardinal point distribution: The cardinal distribution of perches depends on the site. Jenkins (1983) mentioned that some species prefer open, sunny places (e.g. $H$. glauconome and $H$. guatemalena) while others prefer dark parts of the habitat (e.g. H. alicia and $H$. rosandra). As this study concerned species associated with open areas during the time of year when sunlight reached the trees from the south, it could be predicted that the northern side would not be preferred, and this was found in all cases.

Young and Borkin (1985) proposed that Hamadryas use less frequently the windy side, which is less convenient for butterfly courtship flight (Wickman 1988, Wickman et al. 1995). The windy side is the north in Sites 1 and 2 and the northeast in Site 3, thus the hypothesis cannot be rejected for Sites 1 and 2 . When wind speed is not abnormally high, light and temperature may be more important factors (Bitzer and Shaw 1995).

On sunny days, $H$. feronia shows some preferenc for sunny perches and the other species for shadowed perches. In the hot Santa Rosa National Park, $90 \%$ of $H$. feronia individuals perch on the shadow in late morning ( $\mathrm{N}=84$, A.P. Retana, pers. com. 1988) probably to reduce heat stress.

Posture and seasonality: The specific position of the head (upward or sideways) is genetically determined in some moths (Sargent 1969, Sargent and Keiper 1969). In Hamadryas, perching with the head downward may facilitate escape flight, because the insect reaches the flight position simply by skipping (our unpublished analysis of video images).

Reaction to moving objects: Flight towards organisms or objects moving in front of perches is common in many species of lepidopterans and seems to result from poor vision (Tinbergen 1958, Scott 1974, Bitzer and Shaw 1979). The poor vision hypothesis is supported by the reaction of Hamadryas to models - which are examined- and insects such as ants walking near their perches -which are ignored or avoided by walking to another perch. The frequent walking of these butterflies, which greatly surprised Darwin (1839) and has never been explained, may be energetically "cheaper", and less conspicuous to predators than flight.

Experiments with cardboard models: When the model was presented at a distance $H$. guatemalena reacted more often and $H$. februa did the opposite. The former might have a better visual capacity to identify the model as "not interesting" and H. februa may fail to detect it at greater range. Interspecific differences in visual sharpness are known in other butterflies (Bitzer and Shaw 1983).

There was a tendency of $H$. guatemalena individuals to stop reacting after the first tests with the model; this may result from habituation, as suggested by the observation that a male of the species soon stopped reacting to leaves falling repeatedly in front of it.

Removal of resident males and natural interactions: The highly increased frequency with which trees were taken by newcomers after residents had been removed supports the territorial interpretation (Davies 1978).

Although most Hamadryas interactions cannot be considered aggressive, they are territorial because they result in exclusion of the intruder from the tree (see Davies 1978). While male-male interactions mostly end with the newcomer leaving the tree, 2-10 feeding 
individuals can share a tree (Jenkins 1983). Ross (1963) rejected the hypothesis of territoriality in Hamadryas, but his descriptions show that he worked with feeding individuals, not with territorial males.

Wing condition seems unrelated to territorial success, although data are scanty (Davies 1988). In the case of $H$. feronia, males with very damaged wings can retain trees against intruders with fresh wings $(\mathrm{N}=17)$. The damage itself may result from agonistic interactions (Young 1974, Pinheiro 1990) and may characterize highly aggressive males, thus solving Darwin's (1871) paradox (female butterflies copulate with males of poor wing condition). In Hamadryas wing damage actually favors crypsis by making wing outline less conspicuous (pers. observ.).

Effect of time on interactions: Davies (1978) suggested that when territories are relatively abundant, a convention (such as being resident) may decide who stays. That hypothesis is consistent with these data and the abundance of territories for $H$. feronia: one individual uses several trees daily, and each tree has several residents per day and may remain vacant most of the day.

Preferred territories may be visited by more females and provide resident males with more copulations (Bitzer and Shaw 1979, 1983); five trees apparently were more favored by $H$. feronia and had twice as many residents per day than the rest, but no copulations were observed, as usual in butterflies (Pinheiro 1990).

Most interactions took place in the first half of the afternoon, very similar to other butterflies from tropical (Pinheiro 1990) and temperate areas (Baker 1972). A decrease in butterfly territoriality at the beginning and at the end of the mating season is known in temperate species (Baker 1972). H. feronia interactions are less frequent in the dry season (this study) when there is a reduction in abundance and
Hamadryas enters reproductive diapause (Young 1974, Young and Borkin 1985).

The disappearance of any apparent aggression by night and the use of branch tips to perch may reduce predation on the butterflies, as suggested for other insects by Shapiro (1977).

In conclusion, spiral flights vary in frequency with season and time of day. Such flights and the sound emission that often accompanies them seem to have both warning (often territorial) and courting functions.

Sound production: From the many proposed mechanisms of Hamadryas sound production (Swihart 1967, Jenkins 1983, Monge-Nájera 1992) our results ar e consistent only with the hypothesis of forewing collision presented by Seitz (1914) and supported by Otero (1990). However, our conclusion differs from Otero's hypothesis because the $r-m_{1-2}$ have been shown to be only part of the mechanism and because sound is not produced by stridulation as he stated but by percussion (see Dumortier 1963 for detailed definitions). Our sonograms suggest that the two individuals can simultaneously emit sound during joint spiral flights, possibly allowing an early decision about who stays in the territory.

The result of the evolutionary enlargement and modification of veins has been the production of powerful sounds that can be heard by humans at $30 \mathrm{~m}$, probably louder than in any other lepidopteran. Stronger signals may be more effective to deter predators (Busnell 1963), expel territorial intruders (Alcock 1989) and attract mates (Wakamura 1977, Spangler et al. 1984).

Growth of the sound apparatus probably is checked by its effect on flight capacity (Betts and Wootton 1988, Brodskii and Voroblev 1990), physiological costs and ecological 
reasons (e. g. sound may attract predators, Sharp 1899, Surlykke and Gogala 1986).

The ear (cupola) of Hamadryas was identified by Swihart (1967) but this is the first ultrastructural description that has been published. It is basically a stretched membrane that apparently vibrates with sound. The possession of two ears may facilitate detection of sound origin. What has been reported about Hamadryas hearing capacity (Swihart 1967) matches click component frequencies and number of clicks per second.

Sound frequency and signal redundancy in Hamadryas are within the range for lepidopteran sounds (Haskell 1961, Loyd 1974, Kane 1982, Surlykke and Gogala 1986) and fit the requirements to facilitate transmission through vegetation with minimal loss and distortion (Michelsen and Larsen 1983).

The small size, rigidity and organization of Vogel's organ suggests that it is also an ear but specialized in ultrasound, possibly to detect predatory bats. Bats feed on night perching butterflies (Navarro 1995).

Ecology and evolution of sound: Despite the many speculations, the function of sound in Hamadryas had never been studied formally (Jenkins 1983). Captive individuals are known to have courtship with sound $(H$. feronia) and without it (H. februa) and sound has been suggested to attract females to an area (Otero 1988).

The present field study showed that courtship is silent in $H$. februa and noisy in $H$. feronia (pers. observ.) but sound may also have a warning function because it was used in male-male interactions (joint spiral flights) and when large animals approached. At least the large animals were unlikely to be mistaken for females.

Davies (1978) stated that short spiral flights should not be considered aggressive but rather indicative to the passing male that he has intruded in a territory. What are thought to be real aggressive flights, more than $10 \mathrm{sec}$. in duration (Wickman and Wicklund 1983) are very rarely witnessed in Hamadryas and are characterized by an increase in the intensity and frequency of the sound (pers. observ.), but the territorial function seems clear from the result of the male removal experiments.

The variety of mechanisms (references listed in the introduction) suggests that lepidopterans have evolved sound production several times, often for defense (Busnell 1963, Masters 1979) and through natural selection, not through sexual selection. Sexual selection could only explain why male Hamadryas have larger sound-producing structures. For future work we suggest the hypothesis that intraspecific use to warn territory intruders and to attract mates are secondary extensions of that function. As any signal (Pasteur 1972), butterfly sounds may have evolved a complex variety of mimetical mechanisms that represent virgin territory for biological exploration.

\section{ACKNOWLEDGMENTS}

Many people have assisted us during the decade that this project required, and we can only name some of them. Alvaro Castaing R. began the project by suggesting the study of Hamadryas to the senior author 15 years ago, and greatly assisted with early field work, as did Patricia Valverde, Bernal Morera and Sylvia Fernández. Adriana Herrera labeled the illustrations. Carlos Valerio, Alvaro Wille, Juan B. Chavarría, William Ramírez, D.C. Robinson, F.G. Stiles (University of Costa Rica UCR), P. J. DeVries (University of Texas), Luis D. Otero (Central University of Venezuela), Douglas C. Robinson and F. G. Stiles (both UCR), Donald Windsor and Annette Aiello (both Smithsonian Tropical Research Institute, STRI) gave valuable support, assistance and advise. Marco $\mathrm{T}$. 
Saborío produced the photographs. We are thankful for their help. For advise and suggestions to improve sections of earlier drafts we deeply thank four annonymous reviewers as well as Annette Aiello (STRI), R. R. Baker, Robert Dudley (University of Texas), William Eberhard (UCR), Paul Ehrlich (Stanford University), Allen M. Young (Milwaukee Public Museum), Royce J. Bitzer and Kenneth C. Shaw (Iowa State University), Annemarie Surlykke (Odense University), Dale Jenkins (Florida), Robert Srygley (Cambridge University), George Thomson (Dumbrieshire), and Per-Olof Wickman (Stockholm University). William Bussing (UCR) corrected the English text. This research was financed by a STRI Exxon Corporation scholarship, the University of Costa Rica (Vicerrectoría de Investigación 810-87-062), the authors, and Patricia Valverde.

\section{RESUMEN}

Las Hamadryas son mariposas neotropicales que emiten sonido y pasan mucho tiempo posadas en árboles, donde son crípticas. Se estudió cinco especies en Costa Rica y Panama. Cada especie tiene una altura característica para posarse. Se posaron menos del lado sur de los árboles y evitaron las partes soleadas en días calurosos. Los machos dejaron su percha para volar hacia otras Hamadryas y hacia "mariposas" de cartón. Cuando se retiró los machos de los árboles éstos fueron tomados con mucha mayor frecuencia por otros machos. La mayoría de las interacciones aéreas de $H$. feronia se dieron entre las 13:00 y las 15:00 h y fueron más frecuentes en la estación lluviosa. De noche, los machos compartían los árboles. El sonido característico del grupo es producido por venas modificadas en las alas delanteras.

\section{REFERENCES}

Aiello, A. 1992. Dry season strategies of two Panamanian butterfly species, Anartia fatima (Nymphalinae) and Pierella luna luna (Satyrinae) (Lepidoptera: Nymphalidae), p. 573-575 In D. Quintero \& A. Aiello (eds.). Insects of Panama and Mesoamerica: Selected Studies. Oxf ord University, Oxford.

A.lcock, J. 1989. Acoustic Signaling, Territoriality, and Mating in Whistling Moths, Hecatesia thyridion (Agaristidae). J. Insect Behav. 2: 27-37.
Bailey, W. J. 1978. Resonant wing system in the Australian whistling moth Hecatesia (Agaristidae, Lepidoptera). Nature 272: 444-446.

Baker, R. R. 1972. Territorial behaviour of the nymphalid butterflies, Aglais urticae (L.) and Inachis io (L.). J. Anim. Ecol. 41: 453-469

Baker, R.R. 1983. Insect territoriality. Ann. Rev. Entomol. 28: 65-89.

Betts, C.R. \& R. J. Wootton. 1988. Wing shape and flight behaviour in butterflies (Lepidoptera: Papilionoidea and Hesperioidea): A preliminary analysis. J. Exp. Biol. 138: 271-288.

Bitzer, R. J. \& K. C. Shaw. 1983. Territorial behavior of Nymphalis antiopa and Polygonia comma (Nymphalidae). J. Lepid. Soc. 37: 1-13

Bitzer, R. J. \& K. C. Shaw. 1995. Territorial Behavior of the Red Admiral, Vanessa atalanta (Lepidoptera: Nymphalidae) I. The Role of Climatic Factors and Early Interaction Frequency on Territorial Start Time. J. Insect Behav. 8: 47-66.

Bitzer, R. J. \& K. Shaw. 1979. Territorial behavior of the red admiral, Vanessa atalanta (L.) (Lepidoptera: Nymphalidae). J. Res. Lepid. 18: 36-49.

Boardman, M., R.R. Askew \& L.M. Cook. 1974. Experiments on resting site selection by nocturnal moths. J. Zool. London 172: 343-355.

Brodskii, A. K. \& N. N. Voroblev. 1990. The gliding flight of butterflies and role of the wing scale cover in flight (in Russian). Entomol. Obozr. 69: 241-256.

Busnell, R. G. 1963. (ed.). Acoustic behavior of animals. Elsevier, Amsterdam. 933 p.

Calvert, A. S. \& P. P. Calvert. 1917. A Year of Costa Rican Natural History. Macmillan, New York. 577 p.

Cott, H.B. 1946. Adaptive coloration in animals. Methuen, London. $540 \mathrm{p}$.

Daily, G.C., P.R. Ehrlich \& D. Wheye. 1991. Determinants of spatial distribution in a population of the subalpine butterfly Oeneis chryxus. Oecologia 88: 587-596.

Darwin, C. R. 1839. A naturalist voyage. Murray, London.

Darwin, C. R. 1871. The descent of man and selection in relation to sex. Murray, London.

Davies, N. B. 1978. Territorial defence in the speckled wood butterfly (Parage aegeria): the resident always wins. Anim. Behav. 26: 138-147. 
De Vries, P.J. 198.8. Stratification of fruit-feeding nymphalid butterflies in a Costa Rican forest. J. Res. Lepid. 26: 98-108.

Dumortier, B. 1963. Morphology of sound emission apparatus in Arthropoda, p. 277-345 In R. G. Busnell (ed.). Acoustic behavior in animals. Elsevier, Amsterdam. 933 p.

Hampson, G. F. 1892. On stridulation in certain lepidoptera. Proc. Zool. Soc. London 1892: 188-193.

Hannemann, H. J. 1956. Uber ptero-tarsale Stridulation und einige andere Arten der Lauterzeugung bei Lepidopteren. Dtsch. Entom. Z. 3: 14-27.

Haskell, P. T. 1961. Insect Sounds. Quadrangle Books, Chicago. $189 \mathrm{p}$

Hebard, M. 1922. The stridulation of a North American noctuid, Heliothis paradoxus Grote (Lepidoptera). Entomol. News 33: 244.

Jenkins, D. 1983. Neotropical Nymphalidae I. Revision of Hamadryas. Bull. Allyn Mus. 81: 1-146.

Joy, N.H. 1902. (untitled). Proc. Entom. Soc. London 19 Nov: 11-12.

Kane, S. 1982. Notes on the acoustic signals of a Neotropical satyrid butterfly. J. Lepid. Soc. 36: 200206.

Keiper, R.R. 1969. Behavioral adaptations of cryptic moths. IV. Preliminary studies of species resembling dead leaves. J. Lepid. Soc. 23: 205-210.

Kettlewell, H.B.D. 1955. Selection experiments on industrial melanism in the Lepidoptera. Heredity 9: 323-342.

Laithwaite, E., A. Watson, P. E. S. Whalley \& W. D. Duckworth. 1975. The dictionary of butterflies and moths. Joseph, London. $296 \mathrm{p}$.

Lloyd, J. E. 1974. Genital stridulation in Psilogramma menephron (Sphingidae). J. Lepid. Soc. 28: 349-351.

Masters, W. M. 1979. Insect Disturbance Stridulation: Its Defensive Role. Behav. Ecol. Sociobiol. 5: 187-200.

McCrae, A. W. R. 1975. Clicking in flight by an African fruit-piercing moth, Achaea obvia Hampson (Lep. , Noctuidae). Ent. Month. Mag. 111: 161-164.

Michelsen, A. \& O. N. Larsen. 1983. Strategies for Acoustics: Communication in Complex Environments, p. 321-331. In F. Huber \& H. Markl (eds.). Neuroethology and Behavioral Physiology. Springer-Verlag, Berlin.

Monge-Nájera, J. \& F. Hernández. "1991" (1993). A morphological search for the sound mechanism of Hamadryas butterflies. J. Res. Lepid. 30: 196-208.

Monge-Nájera, J. 1988. Mariposas crípticas del género Hamadryas (Lepidoptera: Nymphalidae): uso de sustrato, territorialidad, emisión de sonido y morfología. M.Sc. Thesis, University of Costa Rica, San José, Costa Rica. 61 p.

Monge-Nájera, J. 1992. Clicking Butterflies, Hamadryas, of Panama: Their biology and classification (Lepidoptera, Nymphalidae), p. 567-572. In D. Quintero \& A. Aiello (eds.). Insects of Panama and Mesoamerica: Selected Studies. Oxford University, Oxford.

Navarro P., N. 1995. Incidencia de lepidópteros diurnos en la dieta del murciélago orejudo (Macrotus waterhousei minor Gundlach/Peters, 1865). Garciana (Cuba) 23: 11-12.

Otero, L. D. 1990. The stridulatory organ in Hamadryas (Nymphalidae): Preliminary observations. J. Lepid. Soc. 44: 285-288.

Otero, L.D. 1988. Contribución a la historia natural del género Hamadryas (Lepidoptera: Nymphalidae). Ph.D. Thesis, Universidad Central de Venezuela, Maracay, Venezuela. 108 p.

Pasteur, G. 1972. Le mimétisme. Universitaires de France, Paris. 128 p.

Pinheiro, C.E.G. 1990 (1991). Territorial Hilltopping Behavior of . Three Swallowtail Butterflies (Lepidoptera, Papilionidae) in Western Brazil. J. Res. Lepid. 29: 134-142.

Ross, G. N. 1963. Evidence for lack of territoriality in two species of Hamadryas (Nymphalidae). J. Res. Lepid. 2: 241-246.

Rothschild, M. \& P. T. Haskell. 1966. Stridulation of the garden tiger moth, Arctia caja L. audible to the human ear. Proc. Roy. Entomol. Soc. London (A) 41: 167-171.

Sargent, T.D. \& R.R. Keiper. 1969. Behavioral adaptations of cryptic moths. I. Preliminary studies on bark-like species. J.Lepid. Soc. 23: 1-9.

Sargent, T.D. 1969. Behavioral adaptations of cryptic moths. V. Preliminary studies on an anthophilous species, Schinia florida (Noctuidae). J. N.Y. Entomol. Soc. 77: 123-128. 
Sargent, T.D. 1973. Behavioral adaptations of cryptic moths. VI. Further experimental studies on bark-like species. J. Lepid. Soc. 27: 8-12.

Sargent, T.D. 1985. Melanism in Phigalia titea (Cramer) (Lepidoptera: Geometridae) in southem New England: a response to forest disturbance? J. N. Y. Entomol. Soc. 93: 1113-1120.

Scoble, M.J. 1992. The Lepidoptera: form, function and diversity. Oxford University, Oxford. 389 p.

Scott, F. W. 1968. Sounds produced by Neptis hylas (Nymphalidae). J. Lepidop. Soc. 22: 254.

Scott, J. A. 1974. Mate-locating behavior of butterflies. Amer. Mid. Nat. 91: 103-117.

Seitz, A. 1914. The macrolepidoptera of the World. A. Keman, Stuttgart.

Shapiro, A.M. 1977. Avian predation on butterflies Again. Entomol. Rec. 89: 293-295.

Sharp, D. 1899. Insects. Dover, New York.

Spangler, H. G. , M. D. Greenfield \& K. Takessian. 1984. Ultrasonic mate calling in the lesser was moth. Physiol. Entomol. 9: 87-95.

Steward, R.C. 1976. Experiments of resting site selection by the typical and melanic forms of the moth, Allophyes oxyacanthae (Caradrinidae). J. Zool. London 178: 107-115.

Steward, R.C. 1977 a. Further experiments of resting site selection by the typical and melanic forms of the moth, Allophyes oxyacanthae (Caradrinidae). J. Zool. London 181: 395-406.

Steward, R.C. 1977 b. Industrial and non-industrial melanism in the peppered moth Biston betularia (L.). Ecol. Entomol. 2: 231-243.

Surlykke, A. \& M. Gogala. 1986. Stridulation and hearing in the noctuid moth Thecophora fovea (Tr.). J. Comp. Physiol. 159 A: 267-273.
Swihart, S.L. 1967. Hearing in butterflies (Nymphalidae: Heliconius, Ageronia). J. Insect Physiol. 13: 469-476.

Swinton, A. H. 1877. On stridulation in the genus Ageronia. Entomol. Month. Mag. 13: 207-208.

Thomhill, R. \& J. Alcock. 1983. The Evolution of Insect Mating Systems. Harvard, Cambridge, Massachussetts $547 \mathrm{p}$.

Tinbergen, N. 1958. Curious naturalists. Country Life, London. p. 164-178.

Vogel, R. 1912. Uber die Chordotonalorgane in der Wurzel der Schmetterlingsflugel. Z. Wiss. Zool. 100: 210-244.

Wakamura, S. 1977. Sound production of the male moth Agrotis fucosa (Lepidoptera: Noctuidae) during courtship behaviour. Appl. Entomol. Zool. 12: 202203.

White, F.B. 1877. Stridulation in the genus Vanessa. Ent. Month. Mag. 13:208.

Wickman, P.O, E. García Barros \& C. Rappe-George. 1995. The location of landmark leks in the small heath butterfly, Coenonympha pamphilus: evidence against the hot-spot model. Behav. Ecol. 6: 39-45.

Wickman, P.O. \& C. Wicklund. 1983. Territorial defense and its seasonal decline in the speckled wood butterfly (Pararge aegeria). Anim. Behav. 31: 1206-1216.

Young, A.M. \& S.S. Borkin. 1985. Natural history notes for some Hamadryas butterflies (Nymphalidae: Nymphalinae: Aegeronini) in Northwestern Costa Rica during the tropical dry season. J. Lepid. Soc. 39: 229-235.

Young, A.M. 1974. On the biology of Hamadryas februa (Lepidoptera: Nymphalidae) in Guanacaste, Costa Rica. Z. ang. Ent. 76: 380-393. 


\section{APPENDIX}

Multiple regression results for number of butterflies perching versus several tree factors in Hamadryas butterflies

\begin{tabular}{|c|c|c|c|c|c|}
\hline $\begin{array}{l}\text { Species, Site }(1-3= \\
\text { I-III), R adjusted and } \\
\text { dependent variables }\end{array}$ & $\begin{array}{c}\text { Variables in } \\
\text { model }\end{array}$ & Coefficients & $\begin{array}{l}\text { Species, Site }(1-3= \\
\text { I-III), R adjusted and } \\
\text { dependent variables }\end{array}$ & $\begin{array}{c}\text { Variables in } \\
\text { model }\end{array}$ & Coefficients \\
\hline H. feronia I & Constant & $78.8 *$ & H. glauconome III & Constant & 1.14 \\
\hline \multirow[t]{4}{*}{$0.33 \mathrm{~V}$} & Species & $-75.8 *$ & $0.43 \mathrm{~V}$ & Trunk diameter & 0.01 \\
\hline & Height & 4.2 & & Lichen cover-B & 0.03 \\
\hline & Color & $30.7 *$ & & Lichen cover-C & 0.10 \\
\hline & & & & Lichen cover-E & -0.04 \\
\hline H. februa I & Constant & -2.25 & & Food & 1.70 \\
\hline \multirow[t]{2}{*}{$0.39 \mathrm{~V}$} & Tree & $-0.27 *$ & & $\begin{array}{l}\text { Position in } \\
\text { flight route }\end{array}$ & -2.88 \\
\hline & Height & $0.53^{*}$ & & Color & -0.45 \\
\hline H. feronia I & Constant & $10.46^{*}$ & H.februa III & Constant & 0.80 \\
\hline \multirow[t]{4}{*}{$0.38 \mathrm{DV}$} & Trunk diameter & $23.95^{*}$ & $0.15 \mathrm{~V}$ & Trunk diameter & 0.02 \\
\hline & Color & $8.57 * *$ & & Height & -0.19 \\
\hline & & & & Lichen cover-C & 0.01 \\
\hline & & & & Food & 0.55 \\
\hline H. februa I & Constant & -0.40 & & Texture & -0.46 \\
\hline \multirow[t]{4}{*}{$0.51 \mathrm{DV}$} & Tree & $-0.11 * *$ & & Basic color & 0.27 \\
\hline & Species & $0.04 *$ & & Color & 0.20 \\
\hline & Height & $0.12 *$ & & & \\
\hline & & & H. guatemalena III & Constant & $1.08 *$ \\
\hline H. feronia II & Constant & -0.78 & $0.35 \mathrm{DV}$ & Lichen cover-D & $0.03 * *$ \\
\hline \multirow[t]{2}{*}{$0.15 \mathrm{~V}$} & Species & 0.13 & & Lichen cover-D & $-0.03 * *$ \\
\hline & . & & & Food & $-2.16 * *$ \\
\hline H. amphinome II & Constant & -4.5 & & Position & $1.22 *$ \\
\hline \multirow[t]{3}{*}{$0.40 \mathrm{~V}$} & Trunk diameter & $14.0 * *$ & & & \\
\hline & & & H. glauconome III & Constant & 0.40 \\
\hline & & & $0.31 \mathrm{DV}$ & Trunk diameter & 0.01 \\
\hline H. feronia II & Constant & -0.47 & & Height & -0.06 \\
\hline \multirow[t]{2}{*}{$0.22 \mathrm{DV}$} & Height & 0.15 & & Lichen cover-B & 0.01 \\
\hline & & & & Lichen cover-C & $0.04 * *$ \\
\hline H. amphinome II & Constant & -1.34 & & Lichen cover-E & $-0.02 * *$ \\
\hline \multirow[t]{2}{*}{$0.58 \mathrm{DV}$} & Trunk diameter & 3.85 & & Lichen cover-H & -0.01 \\
\hline & Color & 1.84 & & Color & -0.15 \\
\hline \multirow[t]{8}{*}{ H. guatemalena III } & Constant & 4.15 & H.februa III & Constant & $0.63^{*}$ \\
\hline & Lichen cover-D & $0.17 * *$ & DV & Trunk diameter & 0.01 \\
\hline & Lichen cover-H & $-0.17 * *$ & & Height & $-0.11 * *$ \\
\hline & Trunk diameter & 0.02 & & Lichen cover-A & 0.02 \\
\hline & Food & $-10.0 * *$ & & Lichen cover-C & 0.02 \\
\hline & $\begin{array}{l}\text { Position in } \\
\text { flight route }\end{array}$ & $8.16^{* *}$ & Lichen cover-E & $-0.02 *$ & \\
\hline & Mud & $2.75^{*}$ & & Basic color & $0.53^{*}$ \\
\hline & Basic color & 1.30 & & Color & -0.22 \\
\hline
\end{tabular}

Color: general color of tree bark including epiphytes, Basic color: natural bark color without epiphytes, letters after "Lichen" refer to different sides and heights in the trunk, $1.5 \mathrm{~m}$ above ground: $\mathrm{C}$ south, $\mathrm{D}$ east $\mathrm{E}$ north,F west; $0.5 \mathrm{~m}$ above ground G south, H east, I north, J west. 